Article

\title{
Strategic Planning and Management Model for the Regeneration of Historic Urban Landscapes: The Case of Historic Center of Novi Pazar in Serbia
}

\author{
Esad Muminović $^{1}$, Uroš Radosavljević ${ }^{2, * \mathbb{C}}$ and Džemila Beganović ${ }^{1}$ \\ 1 Department of Technical Sciences, State University of Novi Pazar, Vuka Karadžića 9, 36300 Novi Pazar, \\ Serbia; arhesad@gmail.com (E.M.); dzbeganovic@np.ac.rs (D.B.) \\ 2 Department of Urbanism, Faculty of Architecture, University of Belgrade, Bulevar kralja Aleksandra 73/II, \\ 11000 Belgrade, Serbia \\ * Correspondence: yros@arh.bg.ac.rs
}

Received: 21 December 2019; Accepted: 7 February 2020; Published: 12 February 2020

check for updates

\begin{abstract}
The purpose of this paper is to identify the role of strategic planning as a sustainable tool for regulating both the protection and development of historic urban landscapes, as well as developing an adequate and effective strategic model and management instruments for implementation. The role and importance of strategic planning are examined in the context of global transformative actions in the urban governance of community and private sector engagement and sustainable development on the local level. We argue that a specific-tailor-made-integrated strategic urban planning approach could be a useful model, both for development and urban regeneration and for the preservation of protected valuable historic urban landscapes, thus contributing to a sustainable urban revival of wider surrounding territories including cultural, social and economic development. We stand on the position that the sustainable approach to the protection and revitalization of the historic urban landscapes has to be in line with the acknowledgment of specific local community values, contemporary needs, their involvement, and, eventually, their satisfaction. The case study method was based on the example of a protected historic center of Novi Pazar in Serbia to test the possibilities of applying strategic planning model and management for the implementation tailored to the local context. Eventually, the scenario method was applied to test the possibilities of a simulation of the strategic planning model and management instruments for a protected historic center. We found that the appropriate combination and utilization of regulatory, economic and informational management instruments have to be in place in the specific context. We conclude and draw out theoretical and practical remarks from our research that integrated strategic urban planning model should consider the logic and the functioning of the competitive real estate markets, and the sustainable environmental, economic and social effects, potentials and benefits for the locality where they originate, in order to be utilized as the new generative value both for the protection and for the revival of historic city centers. The paper develops a conceptual strategic planning and management model for the regeneration of historic urban landscapes that capture the physical, environmental, economic, and social effects and indicators of a given space. Based on this input, an adequate initial stage of the conceptual strategy by the authors of the paper was developed for the regeneration of the historic urban city center.
\end{abstract}

Keywords: strategic planning; historic urban landscape; model; management instruments; Novi Pazar; Serbia 


\section{Introduction and Research Methods}

The protection of architectural heritage within historic urban landscapes is a complex area that includes basic protection-research, valorization, legal protection—as well as protection through planning activities and documentation.

The nature of the problem of treatment of protected historic urban landscapes is the fact that urban development and the preservation of architectural heritage in Serbian conditions are seen as the two opposing concepts, while in most Western European countries these two terms represent two sides of the same coin [1]. Part of the professional public often resents the traditional approach of protection and preservation of architectural heritage which hinders and slows down urban development, while, on the other hand, the pressure of development is often perceived as a threat to the survival of cultural heritage [2,3]. However, although there is an opinion that heritage preservation impedes the development of historic urban landscapes, a number of authors point out the role of architectural heritage as a driving force of economic and social development. Tweed and Sutherland [4] emphasize the contribution of cultural heritage in the development of local communities and in meeting human needs. Based on the examples of several cities which base their development strategy on cultural heritage values, Evans [5] points out the positive effects of regeneration and planning interventions in historic urban areas. Current research indicates that cities with cultural heritage have a soft advantage over the competition in the global market [4], which gives them a unique identity.

\subsection{Historic Urban Landscapes Interlinked with Strategic Spatial Planning}

The widespread understanding and appreciation of architectural heritage in recent decades, coupled with the increasingly complex ways of identifying, protecting, preserving and presenting it, has significantly increased the complexity of planning and managing historic urban landscapes. It is clear that a time of enormous uncertainty imposes the need to consider various possible planning patterns that could be continuously adapted to change. Many communities with cultural heritage face problems such as declining real estate values, economic downturns, and leaving the area. In order to preserve life in historic urban landscapes, we need to constantly change our approach and practice, because preserving historic urban landscapes today goes beyond the traditional sectors defined in economic, social and political systems. The consequences of mismanagement are often severe, and not only do they risk the destruction of a valuable architectural heritage, but they often threaten the socio-economic development of the local community.

Cities, including their historic urban landscapes, are at present the focus of economic, social and cultural activities, in which a diversity of interactions creates new initiatives and ideas. To preserve their vitality, historic urban landscapes need to be renewed through a planning approach based on modernization, adaptation and regeneration, while retaining entire complexes, or at least individual buildings, that give the city its character, identity and competitiveness. For these reasons, it is necessary to develop new strategies that can anticipate the complexity of change and create an adequate development and planning platform to act in the new, dynamic ambient [2].

In this sense, in recent decades, a new approach to heritage management has been developed worldwide that treats cultural and historic entities as urban landscapes and became more interlinked with spatial planning in general, and strategic planning in particular. This approach has been promoted by the United Nations Educational, Scientific and Cultural Organization (UNESCO) and International Council on Monuments and Sites (ICOMOS) regarding the integration of historic urban areas. Specific areas of integration and links between heritage management of urban landscapes and spatial planning have been strengthened in several characters and recommendations. As a result, the Nairobi Recommendations [6] brought several planning instruments for the regeneration of historic urban centers and a range of public, community organizations, experts and citizens as stakeholders, while the Washington Charter [7] introduced an integration of economic, cultural and social development policies and urban planning related to urban heritage conservation projects and urban regeneration. Eventually, historic urban landscape as a term was defined in the Vienna 
Memorandum [8], bearing in mind broader territorial context as the new method for heritage conservation and urban regeneration, and comprising assemblages of buildings, structures and open spaces, thus going beyond the traditional historic centers definition.

Finally, Recommendations on the Historic Urban Landscape [9] envisioned that both urban heritage protection and its integration in local sustainable development using spatial planning could contribute to urban identity in the fundamentally changed globalization environment, traditional mass tourism, heritage exploitation, and climate change. The Recommendations recognize that the city is a dynamic organism influenced by economic, social, and cultural forces, and thus use the existing physical fabric, cultural diversity, and local community values integrally as assets in promoting sustainable goals of urban heritage conservation, social, environmental, and economic development. Therefore, this approach focuses on the specifics of local situations in the search for a balance between the protection of architectural heritage, and the economic development, functionality and vitality of the city. Furthermore, it responds to the present needs of residents while improving the city's natural and cultural resources for future generations, which is entirely in line with the notion of sustainability. Above all, it is assumed that the protection and presentation of heritage, economic, environmental and socio-cultural development goals are not conflicting but complementary, and that their long-term success depends on the ways that they are interconnected. An especially important aspect of the Recommendations on the Historic Urban Landscape for this particular research is the call for a range of traditional and innovative regulatory and legislative measures, as well as civic engagement and financial instruments which have to be locally adjusted.

On the urban level, the Recommendations on the Historic Urban Landscape [9] provide principles and guidance for implementing a comprehensive approach to local urban management. These recommendations indicate that the integration of heritage conservation and urban development is a major challenge at the urban level, as it is a very complex process that needs to be addressed at multiple levels [2].

The management of the historic urban landscapes is even more complex because, in addition to concepts related to intangible heritage, it has to include the management of complex social and economic processes $[5,10]$. This approach is holistic and aims to integrate architectural heritage management with a broader socio-economic development framework. This integration applies both to the vertical integration of heritage and non-heritage sectors in institutional terms, as well as to the horizontal integration of the different levels of related urban development and protection policies.

Integrating strategic urban planning with cultural planning is an approach that recognizes the unique value of the architectural heritage, but also the contemporary need for the development of communities related to historic landscapes. The architectural heritage should be seen as a vital ambient for both residents and visitors, especially in the light of the fast-growing cultural tourism. Regarding cultural tourism for increasing the attractiveness of tourist destinations, tourists are becoming more demanding in a globalized world with growing competition and, therefore, the management of any destination should strive to meet the multiple motivations and interests of tourists [11].

The preservation and enhancement of historic heritage are mostly dependent on a formulated local strategy for the protection and enhancement of historic urban landscapes. The strategy should clearly define the overall objectives, which should be based on the principles of sustainability, efficiency, fairness and transparency. The strategy needs to identify existing resources, both material and human resources. Following such a comprehensive analysis, concrete measures need to be developed in order to implement formulated objectives. What is specific to the historic urban landscapes, in relation to other cultural assets, is their dual character. First of all, this is the practical function of the buildings which represent part of the city, in most cases their most significant part, and the cultural functions that the objects themselves possess. Due to this specificity, in addition to the general strategy for the protection of cultural heritage at the national level, it is necessary to develop an integrated urban development strategy at the local level, whose essential aspect would be the preservation and enhancement of historic urban landscapes. 


\subsection{Strategic Plans for the Development of Historic Urban Landscapes}

Since the city is an arena where the fields of action of different sectorial strategies intertwine in the face of constant changes, an integrated strategic concept is proposed in this paper as an adequate planning model. Integrated strategic urban development planning in recent years, regardless of variations in economic structure and population, has been established as standard across Europe. It is based on a model of a spatially compact, mixed-use, socially and culturally integrated city in which the sustainable development conditions are met. This planning model was proposed at an informal meeting of European Ministers of Urban Development, held in the German city of Leipzig in 2007. The main objective of such planning is to pay equal attention to the economic, ambient, social and cultural dimensions through urban development. Planning should find a technical answer and a politically responsible balance between these areas of activity. Urban development planning should provide equal opportunity for various and different social and age groups through the participation of citizens and for the fulfillment of public interest.

The advantage of strategic versus traditional urban planning is reflected in several aspects. The choice of strategic objectives is more reliable due to the hierarchy of strategic planning, which allows the objectives to be defined at higher and implemented at lower levels. In the strategic planning process, the analysis of the situation and the creation of the framework are carried out within the framework of collaborative decision making, and therefore the relationship between local government officials and the public is far more transparent. Strategies should link the different sectors that affect each other and which, with the specific knowledge of experts and stakeholders, should agree on common goals. Of course, there are difficulties in reaching consensus when sectors are representing different interests [12].

A spatial dimension would be a key component for integrated urban development strategies for historic urban landscapes. For each part of the city, the specific integration of sectoral policies that are often interest-oriented would be specifically ensured. In an integrated approach, different thematic areas, levels of government, resources and other actors should be linked. In order to develop this strategy, coordination between different levels of government is needed, facilitated by communication with citizens, the participation of the local economic players, representatives of public institutions and other relevant actors in the planning and implementation of projects and activities. This strategy is expected to improve the process of urban planning and development by linking various institutions and the resources that can be provided. It should be based on the demographic and social parameters of development to ensure the preservation and improvement of quality of life, as well as ensuring social stability [13].

\subsection{Materials and Methods}

We used theoretical research and a literature review from the disciplines of cultural heritage, urban management, and planning for the heritage protection strategies, and experiences in managing protected areas in order to interlink those fields in the introductory part of the paper.

In the second chapter of the paper, we presented a conceptual strategic planning and management model for the regeneration and protection of the historic city centers.

In the third chapter of the paper, we presented the urban planning and governance context in relation to the preservation of protected heritage in Serbia. We have analyzed various types of documentation-reports, plans, documents, and personal experience of dealing with protected heritage and strategic planning.

In the fourth chapter, the strategic planning and management model for the regeneration of historic urban landscapes was tested by a case study method using the example of a protected historic center-Novi Pazar in Serbia. Yin [14] states that the case study method can be useful for more in-depth and comprehensive research for the analysis of a unique situation, like the one in this paper. Justification of a case study method is also underlined by Flyvbjergs [15] since it comes closer to real-life situations. Besides various local government reports, plans, and documents, we used interviews 
conducted with citizens, shop owners, and employees at the Institute for Urbanism and Planning of the City of Novi Pazar and Regional Institutes for the Protection of Monuments to gain their judgment on existing urban heritage values. Their value judgment was used as a starting point for an adequate initial stage of the conceptual strategy, which was done by the authors of the paper for the regeneration of historic city center in order to test the possibilities of applying strategic planning model and policy instruments for implementation tailored to the local context.

In the fifth chapter, the initial stage of the conceptual strategy and management model for the regeneration and protection of the historic center of Novi Pazar was prepared by the authors of the paper as a simulation for the future strategy. The process of the involvement, relation, and organization of different actors is involved in the model as an integral part of goals' and objectives' formulation.

In the concluding chapter of the paper, the sustainability indicators of regeneration strategies for historic city centers are provided in the Conclusion section of the paper. We found that the appropriate combination and utilization of regulatory, economic and informational management instruments have to be in place in the specific context. Additionally, the final section of the article builds on the preceding arguments to consider more directly the implications of the results for the theory and practice of strategic planning and the protection of historic urban landscapes.

The purpose of this paper is to identify the role of strategic planning as a sustainable tool for regulating both the protection and development of historic urban landscapes, as well as for developing an adequate and effective strategic model and management instruments for implementation. The goal is to capture the physical, economic, social and environmental indicators and effects of a given space.

\section{Conceptual Strategic Planning and Management Model for the Regeneration and Protection of the Historic City Centers}

With the purpose of developing the conceptual strategic planning and management model for the regeneration and protection of the historic city centers in this paper, we will use and adapt the theoretical model of urban management in the implementation of strategic projects in Serbia-developed and tested by Radosavljević [16], as shown in Figure 1. The model was tested on several case studies of urban regeneration through large-scale strategic projects and transformative actions in urban management, planning, and governance. Thus, urban management of sustainable urban projects in the model [16] is formulated in a threefold way:

1. As a specific combination of urban governance policy goals and instruments as different strategic options for the regeneration;

2. As a process of involvement, relations, and organization of different actors with often-conflicting interests, values and goals;

3. The range of indicators and effects that an actor's decisions and actions have on sustainability in terms of space/environment, society, and economy.

The purpose of adapting the model of urban management in the implementation of strategic projects [16] to heritage aspects is to make it relevant for the regeneration and protection of the historic city centers. The conceptual strategic planning and management model for the regeneration and protection of the historic city centers proposed in this paper (shown in Figure 2) consists of structural elements based on the aforementioned concepts of urban governance, strategic planning and participatory planning, and the protection and development of cultural heritage and historical urban landscapes.

The structural elements of the conceptual strategic planning and management model for the regeneration and protection of the historic city centers proposed in this paper (shown in the Figure 2) are as follows:

1. Spatial, Social, and Economic Context and the Level of Obsolescence and Dynamics of Historic City Centers;

2. Process of Involvement, Relations, and Organization of Different Actors; 
3. Formulating Strategic Options for the Regeneration of the Historic City Centers;

4. The Sustainability Indicators of Regeneration Strategies for Historic City Centers.

We argue that a specific — tailor-made—integrated strategic urban planning approach could be a useful model for the development and urban regeneration and the preservation of the protected valuable historic urban landscapes. Consequently, creating synergies between development and protection could contribute to the sustainable urban revival of wider surrounding territories, including the cultural, social and economic development of both the historic city center and the city as a whole. In the remainder of this chapter, we will present the structural elements of the conceptual strategic planning and management model for the regeneration and protection of historic city centers.

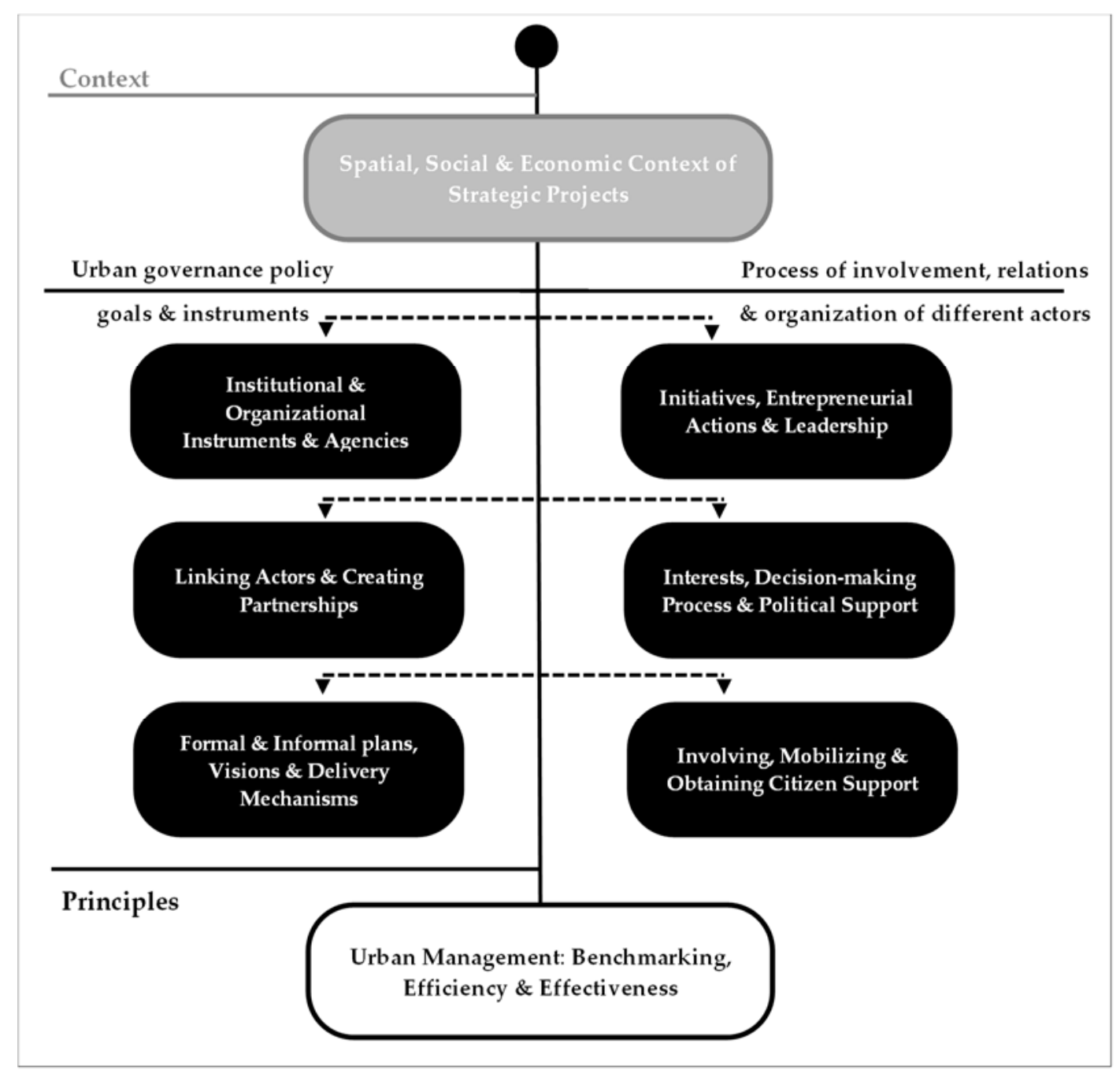

Figure 1. The Model of Urban Management in the Implementation of Strategic Projects in Serbia [16].

\subsection{Spatial, Social, and Economic Context and the Level of Obsolescence and Dynamics of Historic City Centers}

Fundamental changes in society in general, such as globalization and a transformation towards an information and network society and economy [17], as well as economic changes in western countries with the decline of traditional manufacturing industries, caused cities to shift their role from centers of production to centers of consumption [18]. Under those circumstances, historic city centers, regarding their spatial, functional, and physical structure, could not respond anymore to their new, contemporary needs and development dynamics.

Thus, regarding the protection and the development of cultural heritage and historic urban landscapes, Doratli [19] highlights that the proper diagnosis of two contextual characteristics during 
analyses plays a crucial role, even before deciding on the most appropriate strategic approach for the revitalization of historic urban quarters:

1. The level of obsolescence of physical, functional and locational characteristics;

2. The dynamics of the place.

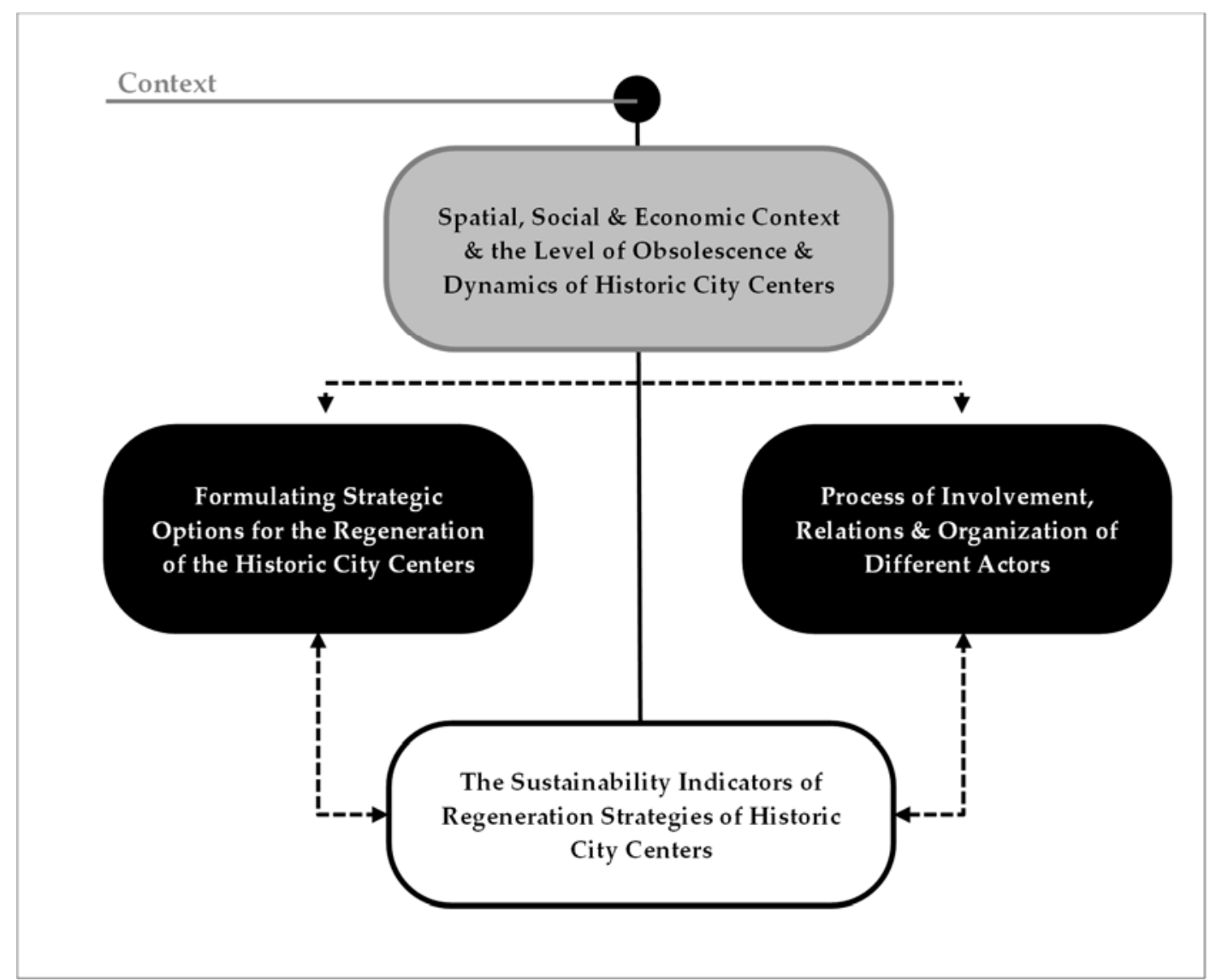

Figure 2. Conceptual Strategic Planning and Management Model for the Regeneration and Protection of Historic City Centers.

The level of obsolescence of historic city centers is directly related to the deterioration of the whole quarter, which usually has narrow streets and buildings used for less suitable purposes, in relation to the contemporary needs of standardization, traffic and energy efficiency and socio-economic, cultural, and political conditions. Thus, an investigation should be made to enlist the buildings in poor overall and sanitary conditions; scarce parking spaces; land uses in general, incompatible land uses, and which of the uses have left for more favorable city districts; changes in the ownership patterns; and surveys on tenure, property values and rent [19].

More specifically, according to Tiesdell, Oc, and Heath [18], the different aspects of obsolescence that have to be considered are:

- Physical and structural obsolescence of the building or an area, which happens with the impact of time, weather, traffic, or through reduced maintenance. Hence, the building needs refurbishment of the physical condition in order to be occupied and functional;

- Functional obsolescence, which might happen when the building is not suitable anymore for its planned function or current utilization by contemporary standards. The same goes for an entire historic area if it cannot comply with parking requirements on the site or in the surrounding streets, or if accessibility problems exist due to narrow streets and street network according to contemporary mobility and accessibility requirements; 
- Image obsolescence, which contributes to the perception and the level of unattractiveness of an area, regarding the uncomfortable traffic flow, noise, smell, and vibration in historic quarters. Such areas become unfashionable due to the lack of contemporary standards and fashionable image. Nevertheless, values change over time and older buildings might be more desirable due to the values of permanence and traditional expectations making deliberate image reconstruction an important element of the revitalization strategy;

- Legal obsolescence, which happens when a local jurisdiction determines new health, safety, fire or building control standards that make the building obsolete, or because the zoning ordinance for the area permits a larger building than the actual one;

- Locational obsolescence, which rests on the functional activities within the area regarding the original central city position of a historic area, where its location was determined in terms of accessibility to other land uses, markets, and transport infrastructure. In present times, due to contemporary polycentric development dynamics and the migration of the central business district, the area becomes unfavorable and obsolete for those activities due to the position of a particular location and shifting of accessibility patterns;

- Financial obsolescence, in which a good or service is no longer desired, especially when a new, better good or service becomes available. Specifically, regarding historic areas, this means that real estate does not have economic value and cannot be used for taxation-it makes the asset disposable. Hence, an issue for regeneration is to make real estate a renewable capital asset instead of a wasted one;

- Relative or economic obsolescence of the historic areas, which is a concept in relation to other buildings and areas, meaning that if the investments in the historic city center are higher than alternative investments in more attractive areas elsewhere, the area is economically obsolete.

The level of obsolescence of historic city centers can be in a close relationship with the economic development dynamics of the area itself and external dynamics of a whole city. These development dynamics, as argued by Doratli [19], can be in a:

- High state of development dynamics, where, although facing physical or functional obsolescence, the area is attractive for investment, with a range of existing employment opportunities and potentially high land values due to property market development pressures to demolish old buildings;

- Static state of development dynamics whilst facing physical or functional obsolescence, since there is neither economic pressure for the development nor for the demolition of historic buildings;

- Without development dynamics, meaning the area is declining in physical, social and economic terms, usually being a slum, or former industrial buildings and warehouses from 19th century urban industrial quarters used for manufacturing, production, and transportation.

\subsection{Process of Involvement, Relations, and Organization of Different Actors}

The public authorities around the world have led, in most cases, the revitalization projects of historic urban quarters in the last two decades of the 20th century-especially the physical component of regeneration-through which the quality of the built environment has been upgraded [19]. However, the preservation and conservation of historic city centers could not occur merely at the public expense [18], thus opening opportunities for the involvement and participation of the private and civil sector. Furthermore, the participation of new social and economic actors is demanded in the governance and urban management of historic quarters, which requires the coordination of multiple actors guided primarily by public institutions and the private sector [20].

The issue in urban regeneration became how urban governments actually stimulate the private sector to invest in public policies and programs [21], beyond the traditional role of the public sector through regulations and the provision of infrastructure. Local governments have, in general, two possible options, according to Vedung [22]: 
- Financial incentives to improve the conditions of actors or reduce the expenditures and risk actions;

- Financial disincentives to depress the condition of actors or to increase the costs and risks of actions.

There are several viable options for urban governments to provide economic incentives for private sector participation, such as different property tax exemptions; or the transfer of development rights from protected areas to new developments, which represent the transfer of floor space indexes that promote the efficient reuse of historic buildings; or as in-kind subsidies of the public sector as a reduction in building land development fees for land uses enabling tourism, cultural tourism, or adaptive reuse of protected buildings [23].

Another possible option in urban regeneration programs for historic areas is creating public-private partnerships. Public-private partnerships are a contractual agreement between a public agency and a private sector, in which the skills and assets, as well as risks and rewards, of each sector are shared in delivering a service or facility with the future benefit of public use [24]. In most cases of heritage protected areas projects, the private sector is not interested in participating in the beginning since there is a gap between the costs of renovation and the value of the property itself. Thus, public sector incentives should be attractive in order to attract private capital and to improve the overall investment environment that will reduce the risk and cost of investing and result in an increase of revenues. According to Rypkema [24], the physical improvement of the surrounding areas and the protected area itself, and the level of public services, can be a critical activity for private sector involvement in the regeneration projects. Public sector commitments to renew infrastructure, streets, and parking systems are often not sufficient to attract the private sector, although they might be a public partner's obligation in joint agreements. In order to increase the probability of the success of such projects, local authorities often adapt the local regulation of land use, zoning, and parking requirements according to the requirements of private partners.

Regarding citizen participation, they are increasingly involved in public life, policymaking, and project implementation at the local level. According to Radosavljević [16], participation can ensure the legitimacy of policies and projects, secure the public interest and introduce new creative ideas, while providing acceptance of and support for decisions made. The degree of involvement in and instruments to mobilize citizens and civic associations varies depending on the specificity of the cultural and social context, political will, and the importance and size of the projects and policies. In this regard, the various degrees of citizen participation refer to variations between:

- Information and communication through the media and other sources of information;

- Consultation, where citizens give their opinions on policies and projects;

- Participation in planning, where citizens participate in projects;

- Participation in decision-making, where citizens have a direct influence on decisions.

Therefore, the whole process of creating strategic urban projects should be transparent and communicate with the public, in order to obtain broad social support from citizens. Broader social support is possible through forums and public debates, live project presentations and the web, etc. [25].

Nevertheless, citizen participation can be controversial, particularly when the cultural heritage protection agencies inadequately perform their functions, usually due to private sector economic pressure, which generally opposes the sustainability and conservation criteria. Azpeitia Santander, Azkarate Garai-Olaun and De la Fuente Arana [20] criticize the involvement of social participation processes in the field of cultural heritage, and thus underline two different types that can be observed:

1. Developing artificial participation reduced to including actors without decision-making powers, only providing symbolic levels of participation in public hearings;

2. Participatory processes with adequate capacity to influence the outcomes of the process that require an in-depth prior debate. 
However, in the case of the citizen participation processes, we have to distinguish that, in the field of cultural heritage, differentiation has to be made concerning any other type of participation in planning and urban design. For instance, in the mid-ring of the city, in which new business or housing schemes make planning efforts easy for city governments and few developers, without strict conservation policies [18]. The same goes for peripheral city locations in which the revitalization and upgrading of depressed areas and public spaces pose elementary and less complicated tasks for city governments. The participation in central historic areas is influenced by contexts with various historic layers and often conflicting interests of different, mainly real-estate property market actors, local business and residents. Thus, participation has limited effectiveness regarding cultural assets in the case of the complex needs of the protection heritage values [20].

\subsection{Formulating Strategic Options for the Regeneration of the Historic City Centers}

Contemporary urban governance and planning considers the visions of development and strategies formulated with the involvement of main stakeholders in the context of understanding market operations, beside classical formal urban plans, land use and regulatory instruments.

In cases of historic urban quarters, Tiesdell, Oc, and Heath [18] argue that the economic problems of historic urban quarters are related to the topics of attracting private investment and encouraging dynamic growth. This is exactly why revitalizing historic urban quarters comprises strategies for the renewal of the physical fabric and the active economic utilization of buildings in historic city centres.

Thus, different aspects of revitalization can be recognized concerning the aspects of sustainability, which, according to Tiesdell, Oc, and Heath can be defined as [18]:

- Physical revitalization of the fabric, which is the adaptation of the physical fabric to contemporary standards using different policy options and instruments of renewal;

- Economic revitalization activities within the fabric of historic city centres, since the private realm and economic activities within the buildings compensate in the long-term for the maintenance of the public realm, including open spaces, thus providing the area with a competitive advantage over other city locations;

- Social public realm of the historic quarter, which must be revitalized and vibrant, which means that the rehabilitated physical attribute of the place and buildings form the frame for an authentic social public realm, which is also a social construct.

After thorough analyses of the level of obsolescence of buildings and areas of historic city centres, and according to the needs of contemporary needs, standards and trends, the improvement and the quality of the physical fabric may be realized through the following modes of renewal [18]:

- Refurbishment, as a form of conservation and consolidation in physical sense which affects the obsolescence of a building or an area to enable its future use;

- Conversion, as a form of adaptive re-use, which Latham [26] defines as a process of modifying a place to suit the existing or new use without diminishing its value;

- Demolition and redevelopment, which, according to Doratli [19], might be an unwanted method for historic centers.

Furthermore, for various levels of different obsolescence, distinctive types of strategic interventions of economic activity can be recognized to ensure revitalization in the long term $[18,19,27]$ :

- Functional restructuring, meaning that new land uses substitute existing uses;

- Functional diversification in terms of introducing new land uses and activities along with the existing uses;

- Functional regeneration as a method of running existing uses more efficiently or profitably.

Based on the identification of the contextual characteristics of the historic city centers and the thorough analyses regarding the levels of different types of obsolescence described previously, 
the relevant different strategic options for the revitalization of historic centers can be recognized. According to Doratli [19], we can distinguish three different strategic options regarding the level of obsolescence and the development dynamics:

1. The first option is for if the area has physical and functional obsolescence, meaning that most of the buildings are old and in poor structural condition, and the fabric of the buildings does not meet contemporary standards, especially sanitary conditions and size, despite monumental and architectural values, but nevertheless, development dynamics are high within the area and attractive for existing functions or other future land uses;

- Governance and policy response of the public authorities aims to create favorable conditions regarding the provision of infrastructure and public spaces, while the restoration and refurbishment of the old buildings should be encouraged in terms of physical revitalization, coupled with economic revitalization if the area in question is still attractive;

2. The second option is if the area is with physical and functional obsolescence and the development dynamics are without redevelopment pressures and static. This further stresses the decay and deterioration of the area, while property values begin to decline, and residents and businesses start to move out of the area, thus influencing changes in the socio-economic situation of the historic city center;

- Governance and policy response of the public authorities means that, besides the physical revitalization, existing land uses should be combined with new ones, used for rebranding and increasing the attractiveness of the area. Functional diversification of land uses and activities should be the right strategic alternative regarding economic revitalization;

3. The third option is characterized by multi-dimensional obsolescence with the declining area, inadequate buildings, incompatible uses that diminish the quality of the environment and decreasing owner-occupied buildings. Development dynamics are in decline and, with the high vacancy rate, low rents and property values, new investment is not present and bypasses the area. These trends contribute to image obsolescence, leaving a burden on the area showing that it is outmoded according to contemporary standards;

- Governance and policy response of the public authorities is to initiate a suitable long-term economic functional restructuring strategy, coupled with capital investments for physical revitalization related to infrastructure and open spaces in order to improve the image and public realm and build confidence in the historic area.

Finally, based on the identification of the contextual characteristics regarding the level of different types of obsolescence of historic city centers, we have to underline that economic, social and physical revitalization have to be considered as complementary in order to achieve a successful and sustainable revitalization of historic urban quarters irrespective of the different strategic options chosen.

\subsection{The Sustainability Indicators of Regeneration Strategies for Historic City Centers}

The evaluation and measurement of the quality and success of the implemented strategic urban regeneration projects according to the urban management model [16] depend on the angle of view, i.e., from public, private, or civil sector positions and, accordingly, the system of values and goals, which each actor defines individually or jointly in the partnership. This also raises questions of efficiency and effectiveness.

Effectiveness refers to issues related to the quality of implemented strategic urban regeneration projects. Issues regarding the effectiveness of strategic urban regeneration projects are related to the values that exist in a particular society and whether solely political representatives define the goals or 
whether goals are defined in interaction with other actors in society in collaborative ways. Thus, the model [16] distinguishes two essential elements concerning efficiency, such as:

1. Realization of goals, indicators and desired outcomes that are formulated in advance and which are directly related to strategic urban regeneration projects;

2. Effects that projects have in the socio-economic terms on the environment and context.

Efficiency refers to the process of implementing strategic urban regeneration projects. Thus, three essential elements concerning efficiency can be distinguished, such as:

1. Issues of direct costs of project realization, and also indirect costs for the residents of the wider territory;

2. The nature and length of the process of realization of certain phases of the project;

3. The proper choice of implementation process concerning the opportunities found in the local context.

Regarding the strategic urban regeneration projects in the urban management model [16], their successful implementation requires a system of developing new urban management and policy instruments and a continuous system of monitoring and evaluating the effects that projects have on urban development. It is necessary to distinguish between the interests and goals that actors have, both individually and jointly in partnerships, so that outcomes are also measured against individual outcomes, and to avoid an overflow of responsibility. Additionally, monitoring the effects of the implementation of strategic urban regeneration projects is important because the actions and projects that do not meet the formulated goals, objectives and performance can be evaluated, changed and adjusted, or even abandoned.

Regarding indicators, there are no standardized sustainability indicators for historic cities and heritage sites, since they have to be adapted to particular needs and specific contexts. Sustainability indicators constantly have to be modified and must be flexible and revisable to allow monitoring, control, and prediction [20].

However, in the quest for an all-embracing typology of sustainable indicators in relation to the revitalization of historic urban quarters in a changing context, we argue that, for the formulation and conception of the regeneration and protection strategy for the historic city centers, as well as for its implementation:

1. The indicators depend on the values and goals conceptualized and agreed through a process involving key actors from the public, private and civil sector in the local context;

2. The outputs and effects of physical, economic and social revitalization have public benefits and added value for all users [16].

Furthermore, the site-specific indicator selection process offers a methodology for combining goals' and objectives' formulation with community participation for the relevant, sustainable indicators of historic cities and heritage areas [27] as:

1. Identification of the community goals with community participation and consultation;

2. Identification of the specific objectives;

3. Determining the causing factors of a specific objective depending on the characteristics of an area;

4. Construction of indicators through enquiring about the causing factors;

5. Creating the initial indicators list;

6. Evaluation of indicators by testing their relevance for a specific case study area;

7. Deciding the final indicators list;

8. The meaning and objectives of the selected indicators;

9. Selection of a method for measuring the indicators; 
10. Analyzing the physical, economic, and social case study environment using multi-dimensional methods (historic, locational; land-use; architectural; transport; social analyzes, etc.)

11. Measuring the selected indicators and defining the sustainability level of the selected case study area and, after conducting the sustainability level measurement of a historic urban area, relating measurements to the revitalization process.

\section{Urban Planning and Governance in Relation to the Preservation of Protected Heritage in Serbia}

The problems facing Serbia are numerous and are mostly conditioned by the changing social, economic, and political ambient. Since the breakup of former Yugoslavia, Serbia has gone through a period of devastating economic, social and cultural crises. Problems with the preservation of cultural heritage have culminated over the last three decades, especially since the beginning of the wars in the territory of former Yugoslavia. Their causes are manifold, ranging from the most dangerous, such as war devastation, through to traditional negligence, the absence of a national strategy in this area and, finally, because of outdated and inapplicable legal regulations [28]. The restitution of several cultural and historical monuments to private owners introduced new actors in the heritage management process. Their behavior, apart from restrictive measures, has not been accompanied by an integral policy or by incentive measures. Due to the slow response of public institutions and low awareness of the new owners, there was an inexperienced restoration or even demolition of monuments and cultural heritage in order to obtain valuable construction land. The insufficient motivation of the decision-makers and lack of public funds for projects restoring historical urban landscapes led to the destruction of many valuable cultural monuments and their surroundings.

An integrative territorial approach to the protection of cultural and natural heritage and landscapes was introduced in the Spatial Plan of the Republic of Serbia from 2010 [29], in accordance with European standards of protection. Nevertheless, although this approach contributes greatly to the recognition of cultural heritage as a resource for sustainable development, the problem remains regarding the legal and institutional framework of protection. That framework is still inconsistent with contemporary conservation approaches, which raises the question of the possibility of implementing planning recommendations. Worth mentioning in this respect is that the Law on Cultural Properties from 1994 is still in power, and it does not comply with international recommendations, nor does it recognize categories of cultural landscapes and historic urban landscapes. Additionally, UNESCO's Recommendations on the Historic Urban Landscape form 2011 [9] have not yet been ratified in Serbia.

Nevertheless, there has been progress in Serbia regarding strategic planning. Priority areas for urban intervention have been identified in the Sustainable Urban Development Strategy of the Republic of Serbia until 2030 [30], linking recognized development problems with specific locations, thus directing local integrated urban development strategies to priority projects. Spatial units with cultural and architectural heritage, important urban settlements as reference points of cultural and historical development, and a group of urban settlements were individually set aside, following the perceived need to extend the subject of protection and the notion of cultural heritage. The following interventions are proposed within the Sustainable Urban Development Strategy-the rehabilitation and revitalization of buildings and architectural heritage; an integrative approach to the protection of cultural property and the urban protection of buildings and entities which are not under institutional protection; the adaptation of architectural heritage buildings according to modern requirements, such as energy efficiency; etc.

Nonetheless, Serbia has to incorporate a number of contemporary United Nations resolutions in its pursuit for its own model of heritage protection. HABITAT III Global Human Settlements Conference 2016 [31] promotes a new, integrative approach to urban planning and decision-making processes for the future of development. Out of the seven important areas for ensuring the sustainable development of cities, the first is urban regulation, land, and management, and the second is planning and design. The third component necessary for lasting prosperity is a financial plan that provides adequate revenue to achieve strategic objectives. 
Advantages and Limitations of the Transition from Conventional to Strategic Planning in Serbia in Relation to Heritage Protection

Following significant social, political and economic changes in Serbia in the early 1990s, there were, among other things, changes in planning and management policies that addressed the issue of protected historic urban landscapes. Although the management and planning of development in protected urban landscapes in Serbia is governed by a set of development and planning documents, as well as by the appropriate institutional framework, the practice has shown that this planning system is not efficient enough. Furthermore, the market pressures for land lead to unavoidable devastation of valuable architectural and urban heritage, which often leads to changes in their functional and spatial characteristics, causing the creation of so-called quasi cultural heritage. The physical degradation of heritage leads to its economic decline, but also to a decrease in real estate value. This loss of economic value has negative effects on the social component of cities, which is reflected in the impoverishment, deterioration, and eventual migration of the local population from historic centers of Serbian cities.

As there is no single strategy for urban development, due to the diversity of local conditions, development planning should address the development of guidelines, models, and action plans and programs. Management plans should provide policy instruments for implementation, as opposed to current project-oriented planning, and strategic plans should provide a link between strategy and implementation. Urban development planning should coordinate between sector strategies and sector policies with spatial resources.

Nevertheless, the transition from conventional to strategic planning is neither simple nor easy. When looking at the international experiences of prosperous cities and the global challenges that historic cities are facing, it is clear that Serbia needs to define fundamental mechanisms as soon as possible. This means that Serbia has to move from an ad-hoc style of making decisions regarding urban development to a systematically organized and defined way of planning development using strategic plans. Vujošević [32] states that the failure of strategic planning in Serbia is the responsibility of an elite that does not have a clear answer to the challenges our country faces. The slow development of civil society institutions is contributing to these processes, as well as poor education, which reduces the value of human capital.

Since citizens in almost all the countries of former Yugoslavia have not yet developed an awareness of their impact on decision-making, in Serbian circumstances the Serbian Government could oblige all local governments to develop a spatial development strategy with the participation of all relevant stakeholders. Based on these assumptions, local governments would develop action plans that could define the exact time and framework for the implementation of agreed goals and objectives. By providing financial assistance for development projects within action plans at the local level, the state would limit local governments to arbitrarily managing the development, with the mandatory condition that funds from the local budget can be spent solely on the implementation of the tasks specified in the action plans, which are derived from development strategies. Controlling the public budget expenditures would make local decision-makers more serious in the process of creating an integrated spatial development strategy as an umbrella document. Indeed, citizens would also be interested in getting involved in the development of the strategy, as the strategy sets priorities and budgetary resources for the implementation of projects. In this way, citizens could formally influence decision-making and the implementation of these projects, because, to date, it has been the practice for politicians to implement projects at their discretion.

Based on the experience of cities in other post-socialist countries, local authorities in Serbia could involve the private sector in the decision-making process and integrate comprehensive urban and financial planning through strategic planning. Furthermore, participation and collaboration should be integral parts of the decision-making process, since strategic plans involve the active participation of stakeholders, and the definition of problems, visions, objectives, and means of implementation [33].

A significant problem in the implementation of strategic urban planning in Serbia is the requirement for institutions to introduce consulting practices through which the legitimacy and diversity of inputs are 
established [34]. It is necessary to establish clear demarcations of responsibilities between institutions to prevent conflicts of interest, especially between governmental and non-governmental organizations, which have a crucial impact on strategic planning. Western Europe has a suitable institutional setting for strategic planning because it has a long tradition of involving all three sectors and embracing public interventions for the common good. Western countries include a large number of partners in urban spatial strategies in decision-making, policy formulation and implementation.

Local governments in Serbia have adopted comprehensive strategic development plans from the year 2000, which are called sustainable development plans in most municipalities, as well as individual sector strategies. A particular problem is that the priorities highlighted in the strategies are not precisely the projects for which they are competing and receiving external funding to finance or co-finance in the implementation process. The existence of development plans does not mean that development is also managed systematically. The main problem is budget preparation and the lack of financial and informational instruments for implementation. Without any reliance on a planning document, local governments often do not follow the plans and deadlines for implementation in strategic documents, and priorities are changed by the will of individuals [35]. Regarding implementation, the success of such plans varies in practice. Strategies are very often informal documents adopted by local governments on their own initiative. The quality of strategies depends on already established procedures, policies, institutionalized practices and forms, value systems and ways of observing phenomena, etc.

\section{The Case Study: Historic City Center of Novi Pazar in Serbia}

Novi Pazar is a town in southwestern Serbia, and the regional, economic, cultural and educational center of Raška region, which still retains its historic name-Sandžak. According to the 2011 census [36], Novi Pazar has 100,431 ethnically heterogeneous inhabitants, comprising $80 \%$ Bosniaks, $15 \%$ of Serbs and a small percentage of other nationalities. The city today covers an area of $742 \mathrm{~km}^{2}$, with an average density of 135 inhabitants per hectare.

The founding of Novi Pazar as a town is linked to the establishment of the Ottoman rule in these areas. The name Novi Pazar is related to the first official document from 1461, when the Republic of Ragusa-today's city of Dubrovnik in Croatia-sent its judges to the town of Novi Pazar. The name was probably due to the existence of the Old Trgovište town with the vast market-place-today's Pazarište site-a medieval settlement from the period of the old Serbian state of Raška located just a few kilometers from the present-day town of Novi Pazar. Both town names literally mean the market place in the Serbian language and are believed to have existed in parallel for some 100 years, when the Old Trgovište town was economically stifled and abandoned [37].

The favorable position along the Raška River on the crossroads and trading routes between neighboring regions of Zeta and Bosnia in the west, and Kosovo and Metohija in the south enhanced the strategic importance of the town of Novi Pazar and its rich cultural heritage. Its historic center as a business and commercial part of the town, with the fortress of Novi Pazar in the vicinity, as part of the once more significant market place, is one of the best-preserved urban heritage sites of its kind in Serbia and was declared the spatial cultural-historical unit of great importance in the Republic of Serbia. The creation of the historic center is related to the construction of the first 56 shops in the newly formed settlement built by the military commander and contributor Isa-beg Isaković. It is believed that during this period, the first public buildings were built, such as the central mosque and the hammam-Turkish bath-that has been preserved to the present day. The historic center was built first on the left and then on the right bank of the Raška river, and reached its peak in the second half of the 17th century, when it was a large and rich oriental historic center, with several small and bigger lodgings, market places, hammams and about 1200 shops. The fact that during the time of the travel writer Evlija Čelebija in the sixteenth century, Novi Pazar had the status of a town-besides Belgrade, Skopje, Sarajevo and only 10 other cities in the occupied Serbian part of the Ottoman Empire-speaks of the richness and development of the city. From the 19th century until liberation from the Turks in 
1912, Novi Pazar achieved a significant degree of economic development, and most of the historical buildings from that period still exist today [37].

The city of Novi Pazar underwent a drastic urban transformation after World War II due to changed socialist ideological conditions, like most of the cities in the former Yugoslavia. The first general urban plan of the city of Novi Pazar was adopted in 1956, and shortly after that a city center project was created in 1968 that would give Novi Pazar a whole new modern spatial and visual identity. With this design of the city center, dominated by high-rise buildings along the arched road forming the wall, the city was symbolically divided into the center and the outskirts [38]. The settlement on the left bank of the Raška River-the historic city center-underwent significant changes during the implementation of this plan. A significant number of buildings were demolished around the town square to form roads and a new Municipal and Cultural Center building.

A significant change occurred in 1977 when the Institute for the Protection of Monuments from the city of Kraljevo recorded monuments and started the research and valorization of cultural heritage in this area. Moreover, a large group of architects and architecture students did their primary research in the period from 1971 to 1973, which served as the basis for the adoption of the General Plan for the Valorization and Protection of the Historic Center of Novi Pazar in 1975. Furthermore, the area of the medieval fortress of Old Ras-one of the first capitals of the medieval Serbian state of Raška—was listed on the UNESCO World Heritage List in the late 1970s. Consequently, a committee for the protection and management of cultural heritage in the municipality of Novi Pazar was established during this period. An important activity of the committee was to implement an appropriate approach for the planning of heritage protection, including the historic city center in Novi Pazar.

Thus, in 1986 and 1987, additional research and documentation of heritage began, which resulted in the development of a detailed plan for the protection and revitalization of the historic city center in Novi Pazar in 1988, under the leadership of Jovan Nesković, professor of architecture and a leading expert in the field of heritage protection and revitalization in the country at that time. Most of the buildings in the historic center were valorized and received legal protection [39]. As a result, significant public buildings in this area were restored during the period of the welfare state in former Yugoslavia.

Another critical period for the historic part of the city was during the 1990s, when the economic and social crisis in Serbia caused many substantial visual and spatial changes to it. The most evident changes were related to the great number of illegal interventions on housing stock in the historic center, e.g., without the consent of the Institute for the Protection of Monuments. Most of the shops modernized their storefronts during that period, which, although appealing in appearance, were not entirely in line with the character of the historic city center. The attitude that it is possible to perform works without obtaining a building permit has been maintained up to the present day, as evidenced by the latest interventions on the Arab Mosque, shown in Figure 3.

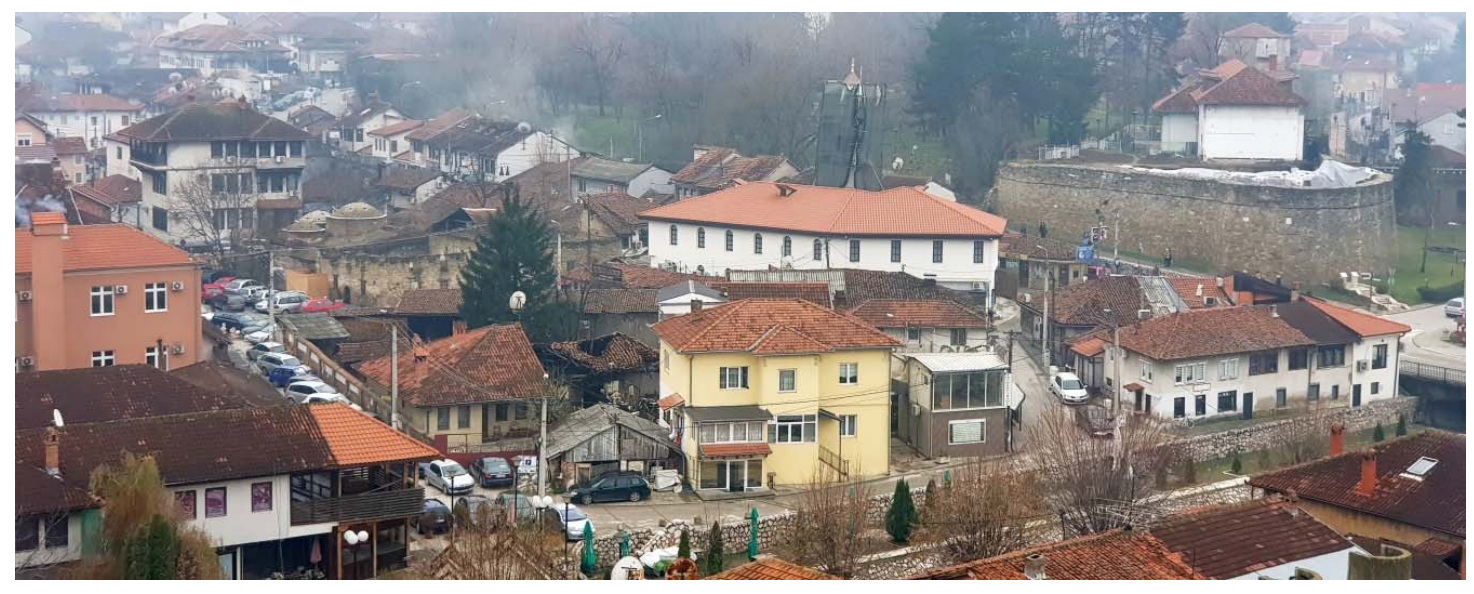

Figure 3. Panorama of the historic center in Novi Pazar with the Arab Mosque under reconstruction. 
From the 2000s, with the recovery of the state and with the market liberalization in Serbia, control over development processes began to be also established throughout the city of Novi Pazar, as well as in its historic part. Those circumstances have influenced a shift from physical to integral socio-economic territorial development, with the introduction of new planning concepts and instruments. Hence, new forms of planning in the form of participatory processes and strategic plans have emerged, including new models of cooperation between municipalities and educational institutions conducted as a simulation of a strategic planning exercise [40]. An essential event for the development of the historic center of Pazar is the adoption of the Plan of Detailed Regulation of the Historic Center with the park in 2017. Although this plan is primarily focused on the arrangement of the physical and spatial layout and land uses, it is an essential basis for the future development of the old historic city center of Novi Pazar.

\subsection{The Context and the Level of Obsolescence and Dynamics in the Historic Center of Novi Pazar: The Physical, Social, Economic, Environmental and Governance Aspects}

\subsubsection{The Spatial and Functional Aspect}

The historic center in Novi Pazar today is one of the rare and relatively well preserved urban heritage sites of its kind in Serbia. In the postwar period, the historic center underwent significant changes, such as its demolition and new construction. In the historic center and its surroundings, many objects of larger volume and inappropriate architecture were built, which did not comply with the standards and character of the historic center. The historic center has remained a vibrant and very active part of the city with a high level of development dynamics; however, many commercial and trade shops have replaced traditional, old wooden windows-for reasons of modernization, cost and energy efficiency-with new modern aluminum and plastic windows in a different color that is not suited to the character of the historic center. Furthermore, a large number of buildings on the 1st of May Street have problems with water supply, plumbing systems and sewage, while some stores do not have any sanitary facilities at all [39].

A significant problem is the fact that a large number of buildings are not in use, and houses in which the old crafts have been situated are being replaced with new uses that are often inconsistent with the historic character of the historic center. Most of the interventions have been done superficially, unprofessionally and without analysis and proper expert approach. The hammam building dating from the 15th century, being the oldest and most important building in the historic center, is not in proper function. The hammam building (Figure 4) was used for a long time as a warehouse, and one part of the facility was converted into a food preparation facility 15 years ago and used only during the summer months, since the roof was demolished. One of the most visually striking objects is the Han Smailbegovića building, popularly known as the Grenade. This facility has been out of service since the 1990s, further contributing to its decay and, eventually, this resulted in the facility burning completely in the 2013 fire.

The replacement of cobblestone asphalt on the 1st of May Street in 1965 and vibrant automobile traffic further shattered the ambiance and atmosphere of the historic center [41]. The condition of the infrastructure is reduced, as asbestos piping has been obsolete a long time ago, while numerous electrical power lines visually pollute this space.

During the 1990s, after the change in the social system and the weakening of the control over construction activities and inspection by the national and local authorities, the historic center has been left to the market forces, and many buildings were illegally constructed and reconstructed resulting in the devastation of the whole historic center. Another feature of modern interventions was the distinction of illuminated advertisements and billboards, which devastated the physical appearance and ambiance of the entire historic center (Figure 5).

Furthermore, due to the massive influx in population from the surrounding areas, the city of Novi Pazar has been exposed to an intense urbanization process in recent years. A large number of the old 
structures located in the contact zone of the historic center have been demolished to provide valuable building land for the construction of multistory residential and commercial buildings (Figure 6).

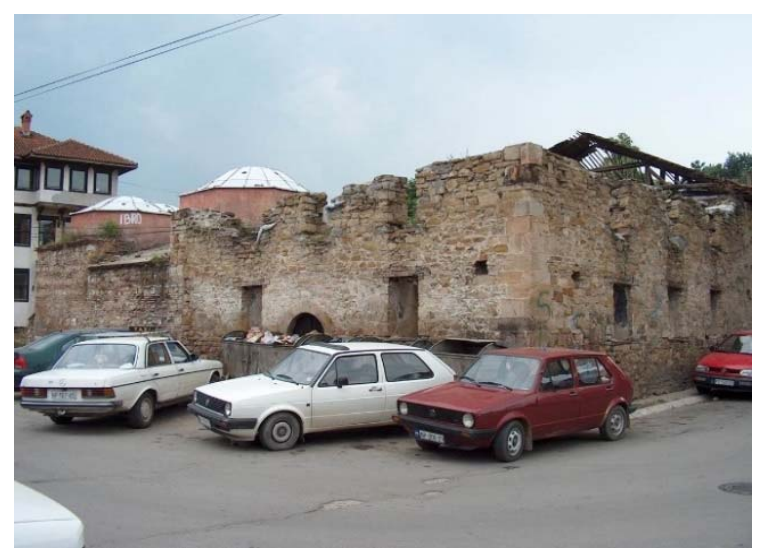

(a)

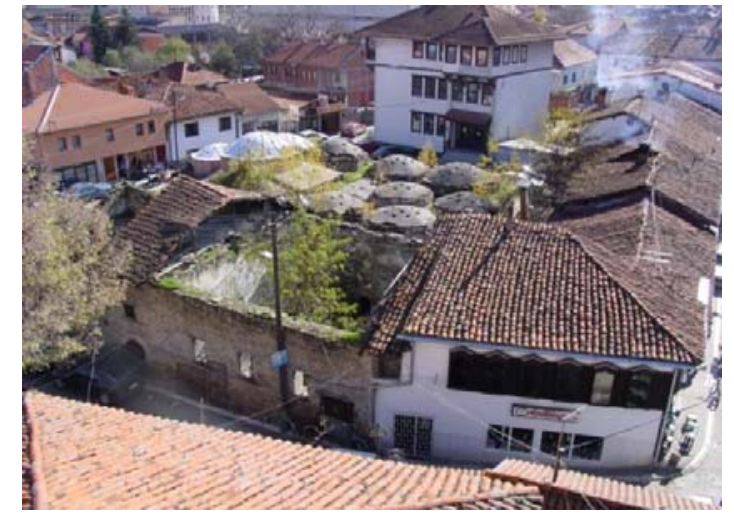

(b)

Figure 4. Hamam of Isa-beg Isaković, 15th century, (a) street view; (b) birds eye view.

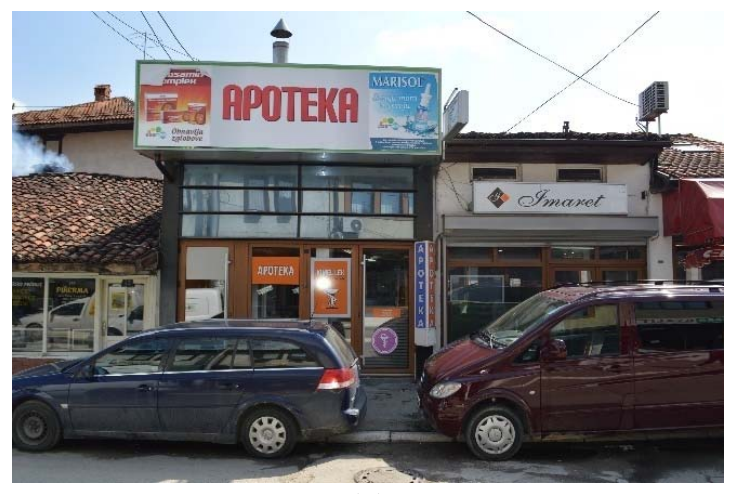

(a)

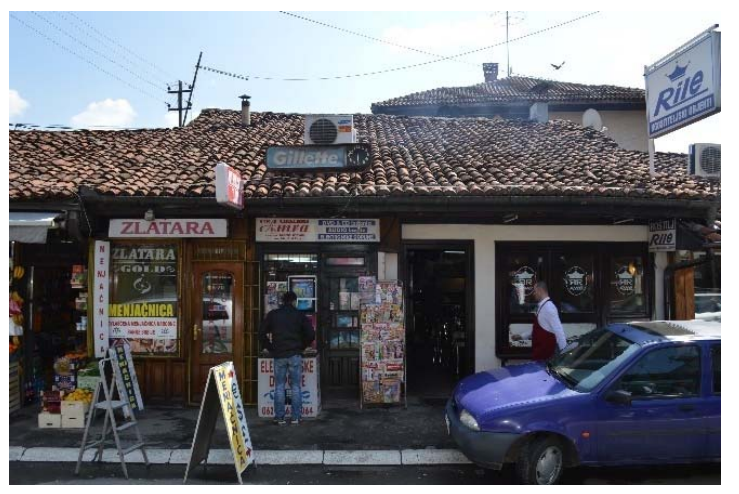

(b)

Figure 5. (a) Placing billboards in the historic center without any order; (b) new shop windows in a different color and material that are not suitable to the character of the historic center.

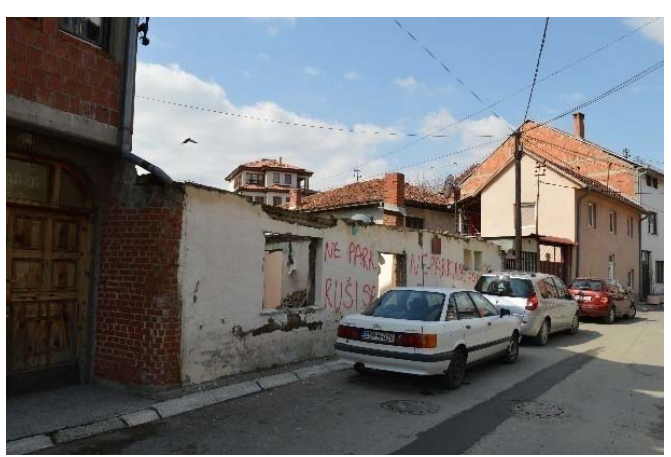

(a)

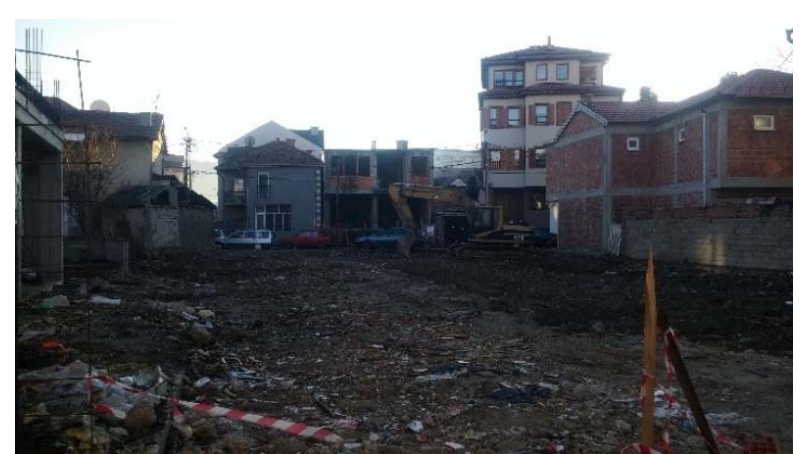

(b)

Figure 6. A cleared site for the construction of a multi-story building in the immediate vicinity of the historic center in the 7th of July Street (a) street view; (b) view of the lot.

These new buildings certainly do not fit the character of the historic center, regarding their height and size, and contribute to the image obsolescence. Another problem is the additional burden of the already existing infrastructure systems of the historic center. Parked vehicles in the narrow and 
winding streets inherited from the past create blockages for the smooth passage of pedestrians and utility vehicles, adding to the functional obsolescence.

\subsubsection{The Social Aspect}

Almost all of the buildings in the historic city center are privately owned. Currently, the biggest problem is the fact that a large number of objects have more than one owner, and a considerable number of them have more than three owners. A substantial number of buildings on the 1st of May Street are owned by the Islamic Community. Since the restitution process of returning confiscated property from the socialist period to its real owners has not yet been completed, court disputes prevent any activity on the objects. It is important to realize that a solution to property ownership issues is a fundamental prerequisite for beginning the process of regenerating the historic center at all.

Another key point regarding social issues is significant research about the inhabitant's and shop owner's satisfaction with the housing options and places of residence in the historic center done by Mulić [42]. The research reveals that the historic center is mainly populated by an older population which is over 50 years old, while a younger population of less than 40 years old lives in the new residential areas of the city [42]. This is explained by the fact that older families find it more challenging to move to new settlements, but there are also financial reasons behind this. Old-town residents are natives that have lived in these facilities for more than 40 years and they constitute 65 percent of the city center population. In terms of education, the older generations generally have completed secondary education, while the younger population living in new settlements have completed higher education. In a survey of 355 respondents, about satisfaction with living conditions and comfort, 15 percent of people answered that were satisfied, 20 percent were partially satisfied, while 65 percent of the surveyed responded that they were not satisfied with the levels of comfort of living in the old city center. Only one percent of residents would demolish their buildings to build new ones, 16 percent thought they could continue living in those buildings with minor renovations, while most, as many as of 64 percent, of residents replied that the facilities should be adaptively reused, while 16 percent of respondents would preserve objects for reasons of nostalgia and historic character and leave them without any use or purpose [42].

\subsubsection{The Economic Aspect}

The economic land uses-such as commercial and trade shops along the 1st of May Street, which is currently one of the busiest streets in the city-are extremely economically valuable as they carry out vibrant economic activity. The trend of opening new bars has recently become noticeable. The entire city, including this historic city center, has seen a rise in property values in recent years due to population growth, greater appreciation of the heritage values and the economic concentration of activities. This dynamic economic activity that puts particular pressure on property owners to modernize their stock. Nonetheless, important to this research is the fact that there is a conflict between the demands for modernization and the preservation of authenticity.

Regardless of this economic growth, the price of land is much lower in the historic center than in the areas directly adjacent to this part of the city. As an illustration of this trend-according to an interview conducted with a private investor who recently bought a building plot on the 1st of May Street-the price of the land in this part of the city ranges from 30 to 50 thousand euros per acre $\left(100 \mathrm{~m}^{2}\right)$. For comparison, the price of land in the new city center-which is about $100 \mathrm{~m}$ away from this part of the city-on the 8th of March Street is between 80 and 100 thousand euros per acre. The price of the land in the historic city center is lower precisely because of the imposed restrictions and the protection zoning regulations in terms of allowed urban coefficients-e.g., the lot coverage, height limitations and floor area ratio (FAR), as well as the poor condition of the existing infrastructure. 


\subsubsection{Environmental Aspect}

Traffic jams and lack of parking space are the biggest problems for the city of Novi Pazar in general and the historic center in particular, adding to the functional and locational obsolescence. This causes numerous environmental problems such as air pollution and damage to the facades of the old heritage buildings. A significant environmental problem is also the pollution of land and water from the sewage outflow from the old sewage system. Moreover, as municipal waste collection vehicles find it difficult to access certain parts of the historic center, the municipal waste containers are full and visually unsuitable for this ambiance. Since there are several butchers on the 1st of May Street, it is common to find trash of animal origin in municipal waste containers, and this situation is not sanctioned by the competent municipal services.

Although the Republic of Serbia has adopted the Ordinance on the Energy Performance of Buildings in 2011 [43], the City of Novi Pazar has only recently begun certifying objects, and therefore accurate data on the energy consumption of individual objects are still unknown. In the same way, while the city has started a few projects related to the reduction of public energy consumption in the form of introducing energy-efficient city lighting, the city's clear commitment to addressing these issues has not yet been seen. Likewise, the issue of increasing the energy performance of public buildings and open spaces in the city's historic core is also of paramount importance.

\subsubsection{Governance Aspect}

The local self-government is mainly committed to solving traffic problems, improving the quality of public spaces, creating preconditions for new investments and solving problems of coping with natural disasters, such as river flooding. Heritage preservation is not a priority issue to be addressed both at the national level and the local level of governance, as the state is confronted with the pressing issues of economic consolidation. Even though there is a department dealing with cultural heritage preservation within the Ministry of Culture of the Republic of Serbia, adequate models for the creation and implementation of a strategy for the preservation and promotion of architectural heritage have not been developed. Similarly, there is no strong political commitment to addressing issues related to heritage protection and revival at the local level. Although the city supports projects for the branding and promotion of heritage regarding tourism development, there are almost no funds from the local budget allocated to the research on and restoration of architectural heritage. This may be due to the complexity of historic center regeneration, since a large number of private actors need to be involved and significant financial resources invested. Another important aspect is that there is a low level of knowledge and skills among municipal experts in the field of heritage protection, management and regeneration related to the new trends and concepts of sustainable development. Additionally, another critical reason for the slow regeneration are the long-lasting and complicated procedures required to obtain building permits, since they have to be obtained at the national level. This is because the historic center is proclaimed a Spatial cultural-historical unit of great importance and falls under the jurisdiction of the republic level of governance.

According to a survey of a sample of 355 respondents [42], 62 percent of residents believe that the city government is responsible for the bad condition of the built heritage, and as many as 16 percent of the population consider that the state and owners themselves are responsible for this situation. Only five percent of the population was unsure who was responsible for this situation. This is important information for all NGOs dealing with cultural issues, to put more pressure on decision-makers to tackle heritage conservation issues in future.

\subsubsection{Problems Derived from the Physical, Social, Economic, Environmental and Governance Aspects}

The main problem was identified and elaborated using a problem tree method (Figure 7). It was done in a participatory manner with representatives of the Novi Pazar city authorities, the Institute 
for Urbanism and Planning of the City of Novi Pazar and Regional Institutes for the Protection of Monuments, and representatives of shop owners and citizens.

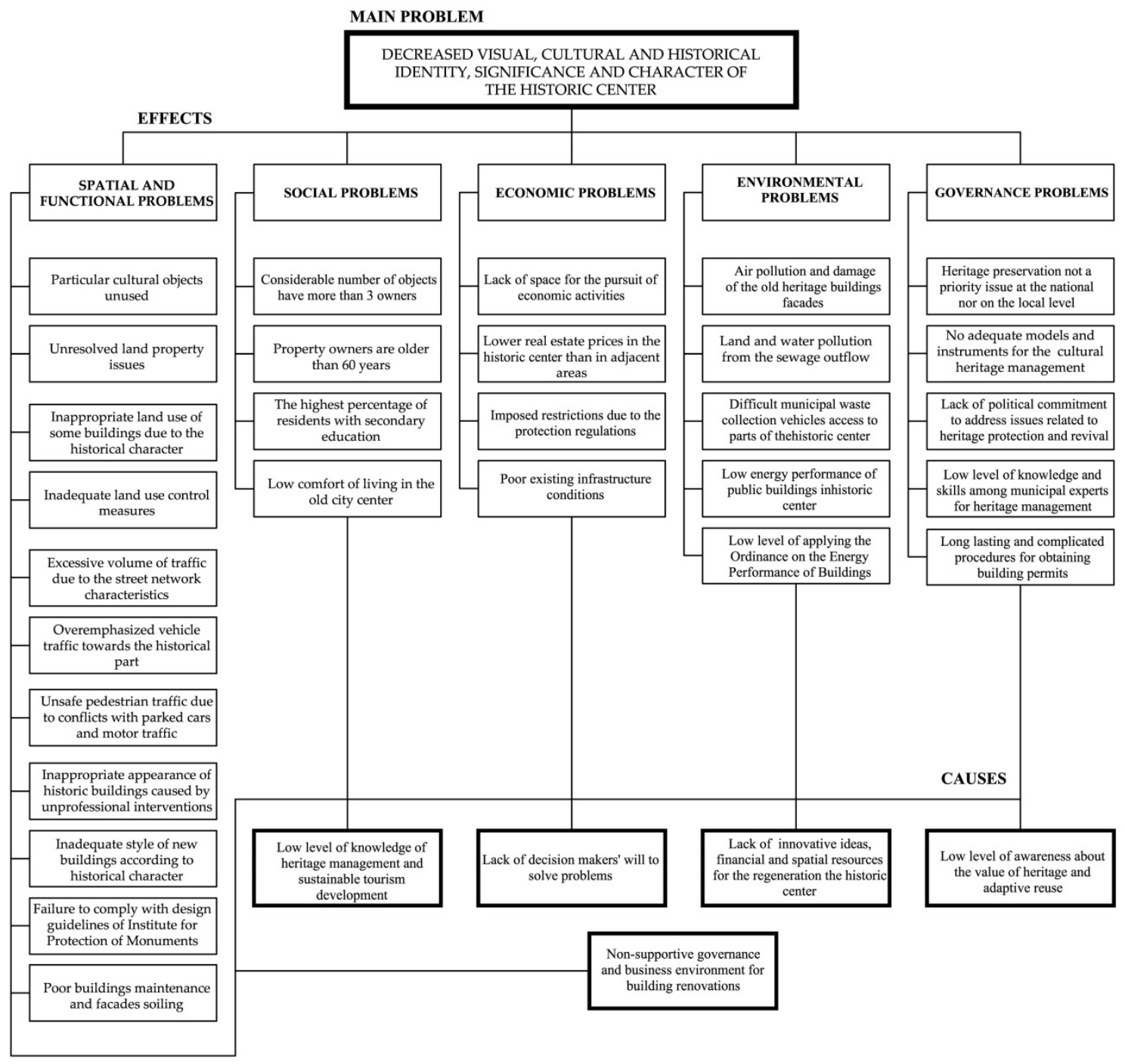

Figure 7. Problem tree.

The final product of this analysis is a graphical representation of problems, differentiated by causes and effects, which focuses on central or essential problems. This technique helps to understand the context and interdependence of problems, as well as the potential influences, when defining the goals of projects and programs. The problems described here were carefully recognized with the aim of identifying the essential main problems, and real causes and effects of dominant problems on different levels.

\section{Initial Stage of the Conceptual Strategy and Management Model for the Regeneration and Protection of the Historic Center of Novi Pazar}

The initial stage of the conceptual strategy and management model for the regeneration and protection of the historic center of Novi Pazar is envisioned as the combination of strategic options for regeneration. Thus, the public sector might create favorable conditions regarding the capital investments and the provision of infrastructure and public spaces for private sector involvement, along with the functional diversification and regeneration of economic activities. Additionally, the public sector can provide economic incentives to obtain private sector participation. Furthermore, goals, 
objectives and actions in this strategy are proposed with the time needed for the implementation. After the initial elaboration of goals and objectives, the strategy is presented in the form of a table with all the stakeholders that should be involved, as well as the particular stage of their involvement.

Renovating the historic city center in a multifunctional way and turning it into a place brand where everyone wants to live and which tourists want to visit by increasing its attractiveness is at the core of a future integrated urban development strategy. In order to achieve this, it is necessary to guide actions in two directions. The first one is an aesthetic, spatial and functional improvement, through the reconstruction of individual objects in order to restore historical character, while the second direction is to provide support and create a favorable environment that will motivate the owners and potential users to renovate their objects and transform them into comfortable objects.

The challenges in achieving these goals are numerous. The quality of the housing currently does not meet contemporary needs. Most of the buildings located in the historic center, are built of cob, which is traditionally referred to as an adobe-cerpič in the Serbian language-on a wooden skeletal structural system bondruk wall. This material is not weather-resistant enough, so frequent renovation of these walls is required. Additionally, a major problem is the lack of knowledge and skilled masons required for the reconstruction of these walls, since they have not been used for the construction of new buildings for many years. Furthermore, urban problems, reflected in the over-concentration of people and motor traffic on the 1st of May Street, places much pressure on the historic city center, as well as the construction of multi-story buildings near the historic center, which do not correspond to its cultural and historic identity, significance and character. Moreover, the urban quality of public spaces is deficient due to the enormous presence of parked cars and asphalt surface treatment, with the cobblestone underneath that was been used to pave streets in the past.

Although the city adopted a Plan of Detailed Regulation for the Historic Center, the plan envisions mainly the physical dimensions of heritage protection and regeneration, focusing only on regulatory instruments, while other aspects of the redevelopment are ignored, such as the economic and informational management instruments. Moreover, the city of Novi Pazar has not applied for heritage reconstruction projects in recent years on the open calls financed by the Ministry of Culture, since the city does not have an integral strategy in place to define the actions which ought to be implemented.

In essence, it is indisputable that the city should develop an integrated urban development strategy as soon as possible, in which the historic part of the city should be given a significant place. When designing the strategy, it is necessary to link all the goals of specific sectoral strategies that the city already has and propose a creative and contemporary way to solve the identified problems. Thereafter, it is necessary to adopt a local action plan for the implementation of the objectives defined in the strategy, using a participatory approach. All the future actions and small projects would involve citizens in some way in order to gain legitimacy and consensus for the implementation of those decisions.

In this respect, it is necessary to use numerous informational instruments in order to involve citizens in this project from the very beginning. Such participatory instruments would include door-to-door questionnaires with selected shop owners and households, online questionnaires, discussions, and meetings on workshop and roundtables with all relevant stakeholders, and through public consultations, in order to understand different users' various issues and their expectations of the particular place, value and identity of the historic center.

In a broader context, at the urban level of the city of Novi Pazar, it is necessary to update the current situation regarding the legal framework for protection, the issue of traffic and mobility in the city in general and in the historic city center, and the current conditions for the conservation of heritage buildings. Besides that, although it is still in the preparatory phase, it is necessary as soon as possible to enable the GIS system as a new digital platform in order to connect different data and information, which should include the current condition of the building conservation process within the historic city center. The use of different policy measures and instruments would prevent further deterioration of traditional buildings, while tighter control of land uses and activities would prevent the 
conflict of incompatible and unsuited uses in the historic city center. Poor quality in the design of new buildings needs to be improved and regulated using strict regulations for an adequate reinterpretation of traditional typologies, building construction and building materials. Additionally, an improved design of public spaces is expected to raise their quality and increase the attractiveness both of the historic city center and the wider territory, in order to reconstruct its image and create a recognizable place brand.

During the process of restoration of individual objects exposed to rapid decay, it is necessary to prevent further decay with various protection measures. Since the city does not have an accurate assessment of endangered vulnerable buildings, it is necessary to form an expert commission, which will enlist all the buildings in this zone and determine their condition. Based on these results, it is necessary to estimate the value and scope of work to be undertaken in order to protect these buildings from further deterioration. Furthermore, it is necessary to examine the energy performance and behavior of these buildings during seismic activity. A large number of buildings had improper interventions in the form of adding concrete elements; therefore, it is necessary to examine the impact of these reconstructions on the original structure. The city should, above all, using its public services and external expertise, examine the condition of local building materials and produce a brochure in the form of guidelines for the restoration of traditional buildings with an emphasis on environmental restoration and the increase of buildings' energy efficiency in this area.

The economic motivation for residents to renew their buildings is shallow, except on the 1st of May Street, in which lively trading activity leads to over-modernization. One way to increase the demand for historic buildings would be through increasing their energy performance. Another way would be to directly subsidize specific conservation works by the city. For example, the city of Novi Pazar-in cooperation with the Institute for the Protection of Monuments in Kraljevo, which has the jurisdiction for all the heritage buildings in this zone-could subsidize up to 70 percent of funds for the replacement of windows on the 1st of May Street. As an effect of this, the city could influence the design of new windows in order to restore the authentic appearance of the shops and increase the value of the entire protected area. Given that there is not a large amount of such buildings, it would not be a significant expenditure for local government in financial terms, while the benefits would be multiplied.

Regarding informational instruments, the need for expanding knowledge and awareness has to be considered crucial. The non-governmental sector, which is still in its development phase, should influence politicians to initiate a procedure for resolving the heritage problem. The strategy and the action plan should envision different activities and instruments, which should be targeted towards investors, architects, engineers, and technicians on the one hand, and towards all citizens on the other.

The city administration should facilitate and overcome numerous administrative procedures in order to reduce bureaucratic red tape and facilitate the issuance of building permits for construction activities. Since a large number of citizens and investors perceive the Institute for the Protection of Monuments in Kraljevo as an institution that slows down their intentions regarding building in the protected historic city center, the city of Novi Pazar should open a local office for the protection of monuments for the historic center. The task of the local office would be to organize meetings in order to increase co-operation between the institute for the protection, and urban planning departments, designers and other stakeholders. The mission of this office would be a significant contribution to overcoming problems and increasing understanding and trust between the institute and citizens. The work of this office could be aimed at increasing the availability of information to citizens and promoting the value of heritage. Furthermore, one of the resulting effects of this office would certainly be helping to coordinate activities when developing projects and seeking donor funding.

Formulating Goals, Objectives and Instruments for the Strategic Planning and Management Model the Regeneration and Protection of the Historic Center of Novi Pazar

The strategic planning and management model should be made for a period of 10 years, and it is desirable that it complies with the programming periods of the European Union (EU). Since this is a 
relatively long period, this plan should be used as a roadmap for achieving the goals defined in the strategy. Furthermore, it is of great importance that the local action plan remains open to revisions and improvements, in line with the challenges and perspectives of the present, thus addressing major urban, social, environmental, economic and governance challenges. Consequently, the main goals of the plan should be the following. One goal should be raising the awareness of municipal, private owners and citizens of the value of heritage, and the involvement of citizens in the decision-making process. Furthermore, the next goal should be the creation of a favorable environment that will stimulate the restoration and protection of traditional buildings for private owners in the historic center. Above all, improvement in the visual image, cultural and historical identity, significance, character and function of the entire historic center by renovating individual buildings, public spaces and inner courtyard private spaces should be the ultimate aim of the strategy.

When drafting the model, it is crucial to identify possible sources of funding. In addition to funds from the local and the national budget, it is important to initiate other direct financial mechanisms or in-kind instruments and credit financing mechanisms. An important source of funding could be European funds-for which Serbia has access to, as a country in the process of accession to the European Community - as well as various other dedicated funds, such as the Turkish Cooperation and Coordination Agency (TIKA) and others that support related activities. TIKA could be extremely interested since the urban matrix and individual cultural buildings in the historic center represent the valuable heritage of the Ottoman rule in these areas. Another financial source could be private donors, since many former residents of the Novi Pazar, Sandžak and the Raška region became wealthy citizens of the EU or Turkey and are willing to invest in and donate to the regeneration of the historic center.

Strategic Goal 1-Improvement of the visual image, cultural and historical identity, significance, character and function of the entire historic center by renovating individual buildings, public spaces and inner courtyard private spaces (Table 1)

The goal of improving the visual image could be achieved by organizing architectural competitions and other studies aimed at improving the urban and architectural quality of the place. Certainly, an important partner in achieving this goal, besides the city, could be the Department of Technical Sciences at the State University of Novi Pazar with its Architecture program. It is also advisable to include professional associations such as the Serbian Chamber of Engineers, Serbian Society of Architects, and the Society of Town Planners of Serbia. An important stakeholder in these processes should be the Institute for the Protection of Monuments from Kraljevo, which eventually needs to accept the proposed solutions.

Important actions should be focused on finding a solution to remove the road traffic from the 1st of May Street and to calm down the traffic in the whole protection zone of the historic center in order to achieve this goal. This has to be done in cooperation with the Institute for Urban Planning and Development Agency of Novi Pazar. The achievement of this goal likely requires the development of a citywide traffic study. An important issue for the management of parking areas should be to find locations for the construction of underground and surface parking garages on the outskirts of the historic city center. Fulfilling this task would reduce traffic in the protected zone and increase the area intended for pedestrians and cyclists, while also solving the problem of parking for the whole city. Additionally, one of the objectives and actions for improving the image and the identity of the historical part of the city should be focused on the aesthetic harmonization of modern buildings constructed after World War II-which are not in line with the spirit of the historic center-with the typical and traditional buildings. Moreover, many new buildings do not have any thermal envelope. By launching energy efficiency projects, many buildings could obtain a new thermal facade or another environmentally friendly cover, such as green and composite eco-materials. This would significantly alter the appearance of historic buildings and address the environmental problem. 
Table 1. Strategic Goal 1: improvement of the visual image, cultural and historical identity, significance, character and function of the entire historic center by renovating individual buildings, public spaces and inner courtyard private spaces.

\begin{tabular}{|c|c|c|c|}
\hline Objectives/Activities and Instruments & Actors/Stakeholders & Timeframe & Priority \\
\hline \multicolumn{4}{|c|}{ Specific objective 1: improving the quality of public spaces } \\
\hline $\begin{array}{l}\text { Organizing urban and architectural competitions for improving } \\
\text { public spaces }\end{array}$ & $\begin{array}{l}\text { State University of Novi Pazar, the Serbian } \\
\text { Chamber of Engineers, Serbian Society of } \\
\text { Architects, and the Society of Town } \\
\text { Planners of Serbia }\end{array}$ & $\begin{array}{l}\text { Mid-range } \\
\text { (6 months) }\end{array}$ & High \\
\hline $\begin{array}{c}\text { Organizing training courses for specialists for the design of buildings in } \\
\text { the historic environment }\end{array}$ & $\begin{array}{l}\text { Institute for Urban Planning of Novi Pazar, } \\
\text { State University of Novi Pazar }\end{array}$ & $\begin{array}{l}\text { Mid-range } \\
\text { (12 months) with } \\
\text { subsequent periodic } \\
\text { repetition }\end{array}$ & Middle \\
\hline $\begin{array}{l}\text { Amendment of the Plan of Detailed Regulation for the historic center, } \\
\text { on the basis of competition for proposed solutions }\end{array}$ & $\begin{array}{l}\text { Institute for Urban Planning of Novi Pazar, } \\
\text { Scientific Research Institute of the State } \\
\text { University of Novi Pazar, private urban } \\
\text { planning offices }\end{array}$ & $\begin{array}{l}\text { Mid-range } \\
(12 \text { months })\end{array}$ & High \\
\hline Proclamation of the historic center as a business improvement district & $\begin{array}{l}\text { The City of Novi Pazar, Institute for Urban } \\
\text { Planning of Novi Pazar }\end{array}$ & $\begin{array}{l}\text { Mid-range } \\
(12 \text { months })\end{array}$ & High \\
\hline $\begin{array}{c}\text { Completion of the inner ring road around the historic center to divert } \\
\text { all vehicle traffic from the area }\end{array}$ & $\begin{array}{l}\text { The City of Novi Pazar, Institute for Urban } \\
\text { Planning of Novi Pazar, Development } \\
\text { Agency of Novi Pazar }\end{array}$ & $\begin{array}{l}\text { Mid-range } \\
\text { (12 months) }\end{array}$ & High \\
\hline $\begin{array}{l}\text { Selection of locations and construction of underground garages in the } \\
\text { vicinity of the historical center }\end{array}$ & $\begin{array}{l}\text { The City of Novi Pazar, Institute for Urban } \\
\text { Planning of Novi Pazar, Development } \\
\text { Agency of Novi Pazar }\end{array}$ & $\begin{array}{l}\text { Mid-range } \\
\text { (12 months) }\end{array}$ & High \\
\hline Introduce time-limited parking in accessible local streets & $\begin{array}{l}\text { The City of Novi Pazar, Institute for Urban } \\
\text { Planning of Novi Pazar, Parking Service }\end{array}$ & $\begin{array}{c}\text { Short } \\
(1 \mathrm{month})\end{array}$ & High \\
\hline $\begin{array}{l}\text { Limit the time of parking for users of commercial and catering facilities } \\
\text { in the historic center }\end{array}$ & $\begin{array}{l}\text { The City of Novi Pazar, Institute for Urban } \\
\text { Planning of Novi Pazar, Parking Service }\end{array}$ & $\begin{array}{c}\text { Short } \\
\text { (1 month) }\end{array}$ & Middle \\
\hline $\begin{array}{l}\text { Monitor the traffic situation on the ground and control its progress } \\
\text { more frequently }\end{array}$ & Police, Parking Service, Municipal Police & Permanent & Middle \\
\hline $\begin{array}{l}\text { Hiring experts for the adaptive reuse of buildings and facades to the } \\
\text { historical and cultural context of the city }\end{array}$ & $\begin{array}{c}\text { The City of Novi Pazar, State University of } \\
\text { Novi Pazar }\end{array}$ & $\begin{array}{l}\text { Mid-range } \\
\text { (6 months) }\end{array}$ & Middle \\
\hline $\begin{array}{l}\text { Media and promotion of heritage using flyers, posters, forums for } \\
\text { citizens and shop owners about the importance of preserving the } \\
\text { heritage and cultural identity of Novi Pazar }\end{array}$ & $\begin{array}{l}\text { The City of Novi Pazar, Media, NGOs, State } \\
\text { University of Novi Pazar, schools }\end{array}$ & $\begin{array}{l}\text { Mid-range } \\
(6 \text { months }) \text { with } \\
\text { subsequent } \\
\text { periodic repetition }\end{array}$ & High \\
\hline \multicolumn{4}{|c|}{ Specific objective 4: designating compatible and suitable land uses for the historic city center } \\
\hline $\begin{array}{l}\text { Stricter control of land uses, as defined in the Plan of Detailed } \\
\text { Regulation, in order to prevent conflict of uses }\end{array}$ & Building Inspection & Permanent & High \\
\hline $\begin{array}{l}\text { In-kind subsidies as a reduction in building land development fees for } \\
\text { land uses enabling cultural tourism }\end{array}$ & The City of Novi Pazar & Permanent & High \\
\hline $\begin{array}{l}\text { Land readjustment to allow for better-suited land uses to the } \\
\text { historic center }\end{array}$ & $\begin{array}{c}\text { The City of Novi Pazar and its planning } \\
\text { department, Institute for Urban Planning of } \\
\text { Novi Pazar }\end{array}$ & Long-range & High \\
\hline A land swap between municipal and privately owned land & The City of Novi Pazar, private owners & Long-range & High \\
\hline $\begin{array}{l}\text { Financial disincentives for land uses incompatible with and unsuited to } \\
\text { the historic center }\end{array}$ & $\begin{array}{c}\text { The City of Novi Pazar and its planning } \\
\text { department, Institute for Urban Planning of } \\
\text { Novi Pazar }\end{array}$ & Long-range & High \\
\hline
\end{tabular}

Furthermore, designating land uses compatible with and suitable for the historic center is an important task to improve the overall image of the historic urban landscape. It is certainly necessary to develop a study in collaboration with all relevant stakeholders in order to revise the existing legal framework of the Plan of Detailed Regulation, which regulates this area in order to preserve the multifunctional character and mixed uses of the historic center. Although the functional diversification of new land uses and activities along with existing uses might be a viable option, an important issue 
should be to control activities that are not prohibited but are not socially acceptable, compatible with, or suitable for the historic center. In recent years, numerous bookmakers and casinos obsessing over the most valuable sites close to the historical monuments are not exempted from this. Additional instruments in the form of regulatory and fiscal disincentives by the local government are needed, that should ban casinos in the cultural and historical part of the city because it sends a bad impression of the value of the heritage. The plan should provide subsidies to traditional crafts workers and their shops, which once inhabited this part of the city, as they are compatible land uses. Currently, these traditional crafts workers are almost completely gone as there is no economic interest for them anymore and they cannot withstand the high price of rent for their shops. Functional regeneration as a method of running existing uses more efficiently and profitably might be the best option.

Strategic Goal 2-Creation of favorable conditions that will stimulate the restoration and protection of traditional buildings for private owners in the historic center (Table 2)

Table 2. Strategic Goal 2: creation of a favorable environment that will stimulate the restoration and protection of traditional buildings for private owners in the historic center.

\begin{tabular}{|c|c|c|c|}
\hline Objectives/Activities and Instruments & Actors/Stakeholders & Timeframe & Priority \\
\hline \multicolumn{4}{|c|}{ Specific objective 1: improving the energy performance of historic buildings } \\
\hline List objects to be upgraded and their condition & Private companies, Building inspections & $\begin{array}{l}\text { Mid-range } \\
(6 \text { months })\end{array}$ & High \\
\hline $\begin{array}{l}\text { Creating a guide with guidelines for improving the } \\
\text { energy efficiency of traditional buildings }\end{array}$ & $\begin{array}{l}\text { Institute for Urban Planning of Novi Pazar, } \\
\text { State University of Novi Pazar }\end{array}$ & $\begin{array}{l}\text { Mid-range } \\
\text { (12 months) }\end{array}$ & Middle \\
\hline $\begin{array}{l}\text { Giving subsidies to improve the energy performance of } \\
\text { traditional buildings and promoting the results of } \\
\text { actions in order to encourage future actions }\end{array}$ & The City of Novi Pazar, Media, schools & $\begin{array}{c}\text { Mid-range } \\
(6 \text { months) with subsequent } \\
\text { periodic repetition }\end{array}$ & Middle \\
\hline \multicolumn{4}{|c|}{ Specific objective 2: introducing subsidies for restoration work and } \\
\hline $\begin{array}{l}\text { Subsidies for citizens who actively adhere to and } \\
\text { promote the recommendations of the Institutes for the } \\
\text { Protection of Monuments and the City of Novi Pazar }\end{array}$ & The City of Novi Pazar & Permanent & High \\
\hline $\begin{array}{l}\text { Subsidizing, by } 70 \% \text { of the value, the replacement of } \\
\text { PVC and aluminum windows in 1st of May Street with } \\
\text { traditional windows }\end{array}$ & $\begin{array}{l}\text { the City of Novi Pazar, Institutes for the } \\
\text { Protection of Monuments }\end{array}$ & Permanent & High \\
\hline \multicolumn{4}{|c|}{ Specific objective 3: improve technical protection measures for cultural heritage and building restoration } \\
\hline $\begin{array}{l}\text { Professional and financial support for private owners in } \\
\text { the design of conservation and restoration projects }\end{array}$ & Local offices of the historic center & $\begin{array}{l}\text { Mid-range } \\
\text { (12 months) }\end{array}$ & High \\
\hline $\begin{array}{l}\text { Carrying out a pilot project for the restoration of a } \\
\text { cultural and historical object in order to effectively } \\
\text { promote restoration }\end{array}$ & $\begin{array}{l}\text { the City of Novi Pazar, Institutes for the } \\
\text { Protection of Monuments }\end{array}$ & $\begin{array}{l}\text { Mid-range } \\
\text { (12 months) }\end{array}$ & High \\
\hline $\begin{array}{l}\text { Holding training workshops for heritage conservation } \\
\text { professionals }\end{array}$ & $\begin{array}{c}\text { the City of Novi Pazar, Institutes for the } \\
\text { Protection of Monuments, State University } \\
\text { of Novi Pazar }\end{array}$ & $\begin{array}{l}\text { Short } \\
\text { (1 month) }\end{array}$ & Middle \\
\hline \multicolumn{4}{|c|}{ Specific objective 4: speeding up procedures for issuing building permits } \\
\hline Opening of a local office for the historic center & Ministry of Culture, the City of Novi Pazar & $\begin{array}{l}\text { Mid-range } \\
\text { (12 months) }\end{array}$ & High \\
\hline $\begin{array}{l}\text { Facilitating procedures for the renovation of buildings } \\
\text { by creating catalogs for typical interventions }\end{array}$ & $\begin{array}{l}\text { the City of Novi Pazar, Institute for Urban } \\
\text { Planning of Novi Pazar }\end{array}$ & $\begin{array}{l}\text { Mid-range } \\
\text { (3 months) }\end{array}$ & High \\
\hline
\end{tabular}

Actions aimed at improving the energy performance of historic buildings would increase the economic value of the buildings themselves and, henceforth, the whole area. Since the number of these buildings is not very large, funds from donor programs for the implementation of this action could be found relatively easily. The renovation and adaptive reuse of historic buildings costs more, than improving the energy performance of contemporary buildings. This discrepancy in the cost of the works could be covered by donor funds or public budget cash flows, and represents a key motivation and financial instrument for private owners to initiate the process of refurbishment and adaptive reuse of their shops and their buildings. Above all, it is imperative to promote the refurbishment and adaptive reuse of traditional buildings that are not under a direct protection regime in this process but represent an essential element of the vernacular architecture and character of the protected cultural and historical landscape. However, there has been a process during recent years of the demolition of these traditional, yet important buildings and the construction of new ones, which all look the same, without any elements of the vernacular and contextual style and architecture. The view of many international 
organizations is that it is crucial to preserve those traditional buildings in their original form and style. This can be achieved only by developing a stimulating and favorable environment where it will be economically viable for the facility to be renovated before it is demolished and rebuilt.

Moreover, to achieve this goal it is very important to obtain the technical support of heritage regeneration specialists, which can be achieved by organizing thematic workshops and training centers. The creation of a digital platform with recommendations and examples of good practice can make a big difference in that respect. Creating promotional materials in digital and hard copy with technical, financial and administrative information is also very important, as well as producing guidelines for the restoration and adaptive reuse of traditional buildings. Indeed, the implementation of this project requires the commitment of the city government, which can facilitate and speed up procedures for obtaining building permits, in the process of the renovation of shops and buildings for citizens and investors.

Strategic Goal 3-raising awareness of municipal, private owners and citizens about the value of heritage, and the involvement of citizens in the decision-making process (Table 3)

Table 3. Strategic Goal 3: raising awareness of municipal, private owners and citizens about the value of heritage, and the involvement of citizens in the decision-making process.

\begin{tabular}{|c|c|c|c|}
\hline Objectives/Activities and Instruments & Actors/Stakeholders & Timeframe & Priority \\
\hline \multicolumn{4}{|c|}{ Specific objective 1: promoting the values of heritage } \\
\hline $\begin{array}{c}\text { Promotion of the cultural and historical heritage of Novi Pazar } \\
\text { through various discussions, forums, media or through } \\
\text { promotional material }\end{array}$ & $\begin{array}{l}\text { The City of Novi Pazar, Media, schools, } \\
\text { NGOs }\end{array}$ & Permanent & High \\
\hline $\begin{array}{c}\text { Organizing discussions and forums about the importance of } \\
\text { preserving cultural heritage, with the inclusion of a large } \\
\text { number of stakeholders }\end{array}$ & $\begin{array}{l}\text { The City of Novi Pazar, Media, schools, } \\
\text { NGOs, State University of Novi Pazar }\end{array}$ & Permanent & High \\
\hline $\begin{array}{c}\text { Introduction of sections in local schools that would study the } \\
\text { culture and cultural heritage of Novi Pazar and the } \\
\text { whole region }\end{array}$ & $\begin{array}{c}\text { The City of Novi Pazar, secondary and } \\
\text { primary schools, State University of } \\
\text { Novi Pazar }\end{array}$ & $\begin{array}{l}\text { Mid-range } \\
\text { (12-24 months) }\end{array}$ & Small \\
\hline \multicolumn{4}{|c|}{ Specific objective 2: involvement of citizens in the decision-making process } \\
\hline $\begin{array}{l}\text { Surveys and questionnaires for all residents and shop owners } \\
\text { in the historic center during all stages of the } \\
\text { strategy development }\end{array}$ & The City of Novi Pazar, media & Permanent & High \\
\hline $\begin{array}{l}\text { Organizing public forums, workshops, individual encounters, } \\
\text { and interviews before making decisions to balance interests } \\
\text { and problems }\end{array}$ & The City of Novi Pazar, media, NGO's & Permanent & High \\
\hline $\begin{array}{l}\text { Informing citizens about all activities related to the } \\
\text { preservation of the architectural heritage and } \\
\text { historic urban landscape }\end{array}$ & $\begin{array}{l}\text { The City of Novi Pazar, media, NGO's, } \\
\text { Local offices of the historic center }\end{array}$ & Permanent & High \\
\hline \multicolumn{4}{|c|}{ Specific objective 3: Improve technical protection measures for cultural heritage and building restoration } \\
\hline $\begin{array}{l}\text { Professional and financial support of private owners in the } \\
\text { design of conservation and restoration projects }\end{array}$ & Local offices of the historic center & $\begin{array}{l}\text { Mid-range } \\
(12 \text { months })\end{array}$ & High \\
\hline $\begin{array}{l}\text { Carrying out a pilot project for the restoration of a cultural } \\
\text { and historical object in order to effectively promote restoration }\end{array}$ & $\begin{array}{l}\text { the City of Novi Pazar, Institutes for the } \\
\text { Protection of Monuments }\end{array}$ & $\begin{array}{l}\text { Mid-range } \\
(12 \text { months })\end{array}$ & High \\
\hline $\begin{array}{l}\text { Holding training workshops for heritage } \\
\text { conservation professionals }\end{array}$ & $\begin{array}{l}\text { the City of Novi Pazar, Institutes for the } \\
\text { Protection of Monuments, State University } \\
\text { of Novi Pazar }\end{array}$ & $\begin{array}{l}\text { Short } \\
\text { (1 month) }\end{array}$ & Middle \\
\hline \multicolumn{4}{|c|}{ Specific objective 4: Speeding up procedures for issuing building permits } \\
\hline Opening a local office for the historic center & Ministry of Culture & $\begin{array}{l}\text { Mid-range } \\
\text { (12 months) }\end{array}$ & High \\
\hline Opening a local office for the historic downtown & the City of Novi Pazar & $\begin{array}{l}\text { Mid-range } \\
\text { (3 months) }\end{array}$ & High \\
\hline $\begin{array}{l}\text { Facilitating procedures for the renovation of buildings by } \\
\text { creating catalogs for typical interventions }\end{array}$ & $\begin{array}{l}\text { the City of Novi Pazar, Institute for Urban } \\
\text { Planning of Novi Pazar }\end{array}$ & $\begin{array}{l}\text { Mid-range } \\
\text { (3 months) }\end{array}$ & High \\
\hline
\end{tabular}

Raising awareness about the value of cultural and architectural heritage should be directed to all citizens and all age groups. When implementing these programs, it is important to identify and involve all relevant actors, both when drawing up these plans and later in their implementation.

Furthermore, to achieve this goal it is of utmost importance to use a variety of participatory techniques, such as workshops, roundtables, and public consultations, that would all serve as a platform for establishing a dialogue among various stakeholders and their interests. If practiced in this particular way, the process can eventually gain legitimacy and, in the end, secure the commitment of various stakeholders. 


\section{Conclusions}

The existing model of planning and management of historic urban landscapes in Serbia does not contribute to the adequate preservation of the architectural heritage and does not correspond with the interests of local development. Numerous examples have shown that existing plans are inflexible, inefficient and unrealistic when concerning the requirements for the development of historic urban landscapes. Although this area is regulated by a whole set of development and planning decisions, the example presented in this paper, of the case of Novi Pazar, shows several functional, economic, social and ambient problems, and aspects of obsolescence, that these areas face. The physical changes that take place in these areas often do not match their historical character, thus the result is degradation, obsolescence, devastation or the creation of a so-called quasi-cultural heritage. Although some formal shifts have been made in the structure and content of various aspects of urban plans in recent years, there is still no positive step towards the protection and development of historic urban landscapes in Serbia.

All things considered, the research reveals that the most important goals of urban regeneration, protection and the development of historic urban landscapes are related to the potential for economic development, improved quality of life for residents and tourists, and the conservation of built and cultural heritage while promoting cultural and historical identity.

Given these points, it is important to underline that, although particular urban revitalization plans and projects have to be adapted to specific contexts and situations, in order to be successful and represent a benchmark for other places they should include the following objectives and instruments:

- Provide applicable methods, strategies, instruments, and procedures for the urban regeneration of historic city centers, including the protection and conservation of cultural heritage and the rehabilitation of protected buildings with historic value;

- Secure zoning and building regulations which are flexible to heritage issues, stimulate urban regeneration and development, and promote the refurbishment and adaptive reuse of built heritage, rather than demolition and redevelopment;

- Deliver economic and financial instruments for funding the reconstruction of public infrastructure, public spaces and the rehabilitation of private buildings;

- Provide economic and financial instruments for enabling the economic development of the heritage area in order to create a favorable environment for the involvement of the private sector through public-private partnerships;

- Obtain the participation of residents of historic city centers and other relevant civil sector stakeholders' in the regeneration process using a number of various participatory techniques, to gain legitimacy and secure their commitment, while taking their needs into account in relation to the potentials and limitations of the area in question in order to secure long-term public benefits for the society and the values of tangible heritage.

Monitoring and evaluation of the selected actions is necessary throughout the implementation phase in order to obtain an efficient and effective process. Therefore, it is necessary to form a criteria and indicators for the success of the realization in order to facilitate the monitoring and the accomplishment of tasks. Depending on the necessary time, resources and complexity of procedures, the ranking of the measures given could be easy, medium, and challenging. This process is essential to make recommendations for the design of future models in order to interlink strategic planning and development with historical urban landscapes.

In this respect, a useful innovative instrument for the governance of the urban regeneration projects-particularly the economic appraisal within projects that could be used in a public-private partnership—is the experimental model of the "economic feasibility project for the development of unused public buildings" called SOSTEC [44]. Besides the fact that the model provides an economic evaluation of the real estate adaptive re-use projects-including criteria to assess costs and revenues for better insight into economic sustainability-equally important is that the model allows for the involvement of local stakeholders' knowledge and points of view about the ongoing or implemented 
programs. These previously mentioned points of the model characteristics —in our view-provide possibilities for tailor-made solutions at the local level of governance. This model and approach could be a very useful instrument both during the conception of the strategic and action plan, as well as during the implementation phases for monitoring and reevaluation.

Besides the conceptual strategic planning and management model for the regeneration of historic urban landscapes, based on a methodology for the sustainable appraisal of the historic environment [45], measuring and evaluating culture's contribution to regeneration [5], the model for measuring the sustainability level of historic urban quarters [27] and our own research, the paper develops spatial, economic, and social goals, indicators and effects of regeneration strategies of historic city center, presented in Table 4.

Table 4. Spatial, economic, and social goals, sustainability indicators and effects of regeneration strategies of historic city centers.

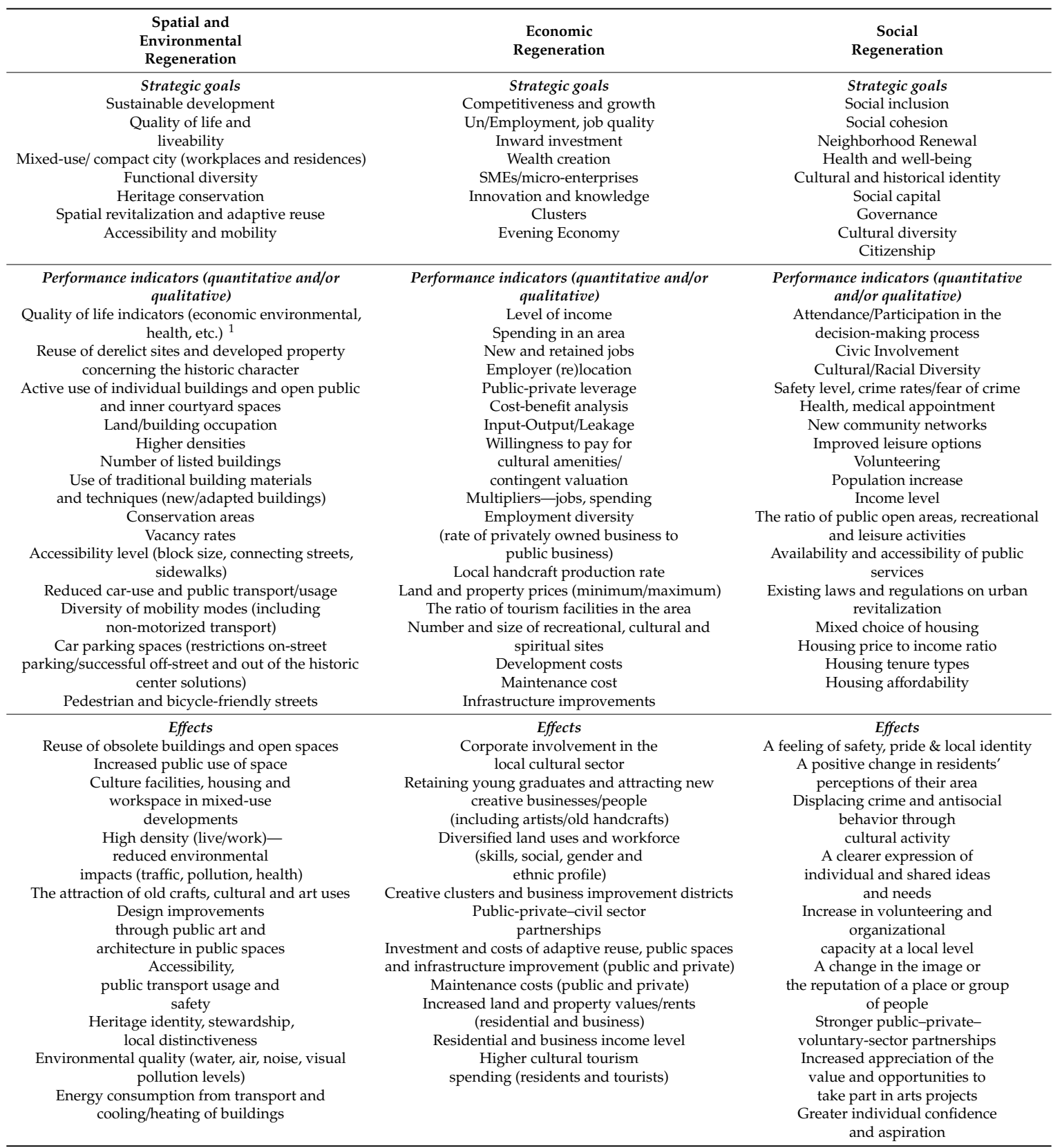

${ }^{1} 8+1$ dimensions of quality of life [46]. 
Some lessons and recommendations could be drawn here based on the research presented in this paper, which could influence the implementation of an integrative approach to the protection and planning of cultural heritage in the frame of urban development and regeneration. However, an important prerequisite for such an integrative approach is the improvement of the institutional, legal and management framework and strategic planning methodology. Lessons and recommendations are as follows:

- Expanding the concept of cultural heritage to the urban heritage protection for objects and entities that are not declared as cultural heritage monuments in accordance with international recommendations and standards, especially with the Recommendations on the Historic Urban Landscape [9];

- Introducing a territorial approach: cultural heritage is an inseparable part of the living environment, both built and natural, and cannot be separated under the jurisdiction of sectoral institutions; it must be viewed in correlation with its immediate environment and satisfy contemporary functions and users' needs, including residents, investors and tourists;

- Improving the institutional and legal framework for the protection, planning and management of cultural heritage by expanding the subject of protection and strengthening cross-sectoral cooperation through the introduction of an integrative approach to the protection of the heritage;

- Improving the planning methodology through the introduction of an integrative strategic planning approach and concept of urban protection in formal statutory plans and the introduction of practical guides and methodologies for contextual analysis and valuation of the built cultural heritage;

- Introducing strategic planning models, management instruments and a financing system for the protection of heritage - both for individual buildings and historic urban landscapes—and for wider spatial, social, environmental and economic sustainable regeneration, with positive impacts and benefits for the localities from which they originate.

The strategic model for planning the protection and the development of historic urban landscapes is presented in this paper as an adequate planning model, which can represent an effective model for the implementation of a cultural heritage protection strategy in a sustainable way in the light of constant changes, crises, and uncertainties. The paper presents this planning model as a step forward from the conventional planning model, and in doing so, can respond to global and local, social, political and economic changes, aligning the needs and interests of a wide range of actors and stakeholders with realistic development opportunities.

It has been suggested [47] that heritage protection can learn from strategic planning by using various participatory instruments to include different actors' interests according to the contemporary community's needs, thus serving the public good. Their research also underlines the proper combination of various economic, social, and environmental instruments for achieving sustainable, comprehensive visions of development.

In order to secure long-lasting, sustainable and comprehensive visions of development, a condition is to have the significant relevant stakeholders engagement throughout the process, which "can bring new belief in the community that their specific places could be successfully branded and planned based on cohesive spatial visions" [40].

We conclude by giving theoretical and practical remarks from our research: integrated conceptual strategic urban planning model should consider the logic and the functioning of the competitive real estate markets on the one hand, and sustainable environmental, economic and social effects, as well as the potentials and benefits for the locality where they originate on the other hand, in order to be utilized as the new generative value both for the protection and for the revival of historic city centers.

Author Contributions: Conceptualization, E.M. and U.R.; Funding acquisition, E.M. and U.R.; Investigation, E.M., U.R. and D.B.; Methodology, E.M., U.R. and D.B.; Visualization, E.M. and U.R.; Writing-original draft, E.M. and U.R.; Writing-review and editing, E.M., U.R. and D.B. All authors have read and agreed to the published version of the manuscript. 
Funding: This research was funded by the Ministry of Education, Science and Technological Development of the Republic of Serbia, under the Grant number TR 36035 "Spatial, Environmental, Energy and Social Aspects of Development of Settlements and Climate Change".

Acknowledgments: This paper is partially the result of the ongoing doctoral research by Esad Muminović, and partially the result of the research within the TR 36035 "Spatial, Environmental, Energy and Social Aspects of Development of Settlements and Climate Change" by the Ministry of Education, Science and Technological Development of the Republic of Serbia conducted by Uroš Radosavljević.

Conflicts of Interest: The authors declare no conflict of interest.

\section{References}

1. Van Oers, R.; Pereira Roders, A. Historic cities as model of sustainability. J. Cult. Herit. Manag. Sustain. Dev. 2012, 2, 4-14. [CrossRef]

2. Bandarin, F.; Van Oers, R. The Historic Urban Landscape-Managing Heritage in an Urban Century; Wiley-Blackwell: Chichester, UK, 2012.

3. Getty Conservation Institute. Historic Urban Environment Conservation Challenges and Priorities for Action Experts Meeting; The Getty Conservation Institute: Los Angeles, CA, USA, 2010; Available online: http://www. getty.edu/conservation/publications_resources/pdf_publications/pdf/experts_mtg_mar09.pdf (accessed on 4 October 2019).

4. Tweed, C.; Sutherland, M. Built cultural heritage and sustainable urban development. Landsc. Urban Plan. 2007, 83, 62-69. [CrossRef]

5. Evans, G. Measure for Measure: Evaluating the Evidence of Culture's Contribution to Regeneration. Urban Stud. 2005, 42, 959-983. [CrossRef]

6. UNESCO. Recommendation Concerning the Safeguarding and Contemporary Role of Historic Areas; UNESCO: Warsaw, Poland; Nairobi, Kenya, 1976.

7. ICOMOS. Charter for the Conservation of Historic Towns and Urban Areas (Washington Charter); ICOMOS: Washington, DC, USA, 1987.

8. UNESCO. Vienna Memorandum on 'World Heritage and Contemporary Architecture-Managing the Historic Urban Landscape'; UNESCO World Heritage Centre: Paris, France, 2005.

9. UNESCO. Recommendation on the Historic Urban Landscape; UNESCO World Heritage Centre: Paris, France, 2011.

10. Jokilehto, J. International Charters on Urban Conservation: Some Thoughts on the Principles Expressed in Current International Doctrine. City Time 2007, 3, 23-42.

11. Huete-Alcocer, N.; López-Ruiz, V.R.; Grigorescu, A. Measurement of Satisfaction in Sustainable Tourism: A Cultural Heritage Site in Spain. Sustainability 2019, 11, 6774. [CrossRef]

12. Tsenkova, S. Urban Planning and informal cities in Southeast Europe. J. Archit. Plan. Res. 2012, $29,292-305$.

13. German Association of Cities. Strategies and instruments for sustainable urban development. In Integrated Urban Development Planning and Urban Development Management; The German Association of Cities: Berlin, Germany, 2013.

14. Yin, R.K. Case Study Research: Design and Methods, 2nd ed.; Sage: Thousand Oaks, CA, USA, 2009.

15. Flyvbjerg, B. Five Misunderstandings About Case-Study Research. Qual. Inq. 2006, 12, 219-245. [CrossRef]

16. Radosavljević, U. Formation of the Urban Management Model in the Implementation of Strategic Projects. Ph.D. Thesis, University of Belgrade-Faculty of Architecture, Belgrade, Serbia, 2014.

17. Castells, M. The Rise of the Network Society, 2nd ed.; Blackwell Publishing: Oxford, UK, 2010; Original Work Published 1996; Volume I.

18. Tiesdell, S.; Oc, T.; Heath, T. Revitalizing Historic Urban Quarters; Architectural Press: New York, NY, USA, 1996.

19. Doratli, N. Revitalizing historic urban quarters: A model for determining the most relevant strategic approach. Eur. Plan. Stud. 2005, 13, 749-772. [CrossRef]

20. Azpeitia Santander, A.; Azkarate Garai-Olaun, A.; De la Fuente Arana, A. Historic Urban Landscapes: A Review on Trends and Methodologies in the Urban Context of the 21st Century. Sustainability 2018, 10, 2603. [CrossRef] 
21. Fainstein, S. The City Builders. Property Development in New York and London, 1980-2000, 2nd ed.; University Press of Kansas: Lawrence, KS, USA, 2001; Original Work Published 1994.

22. Vedung, E. Policy Instruments: Typologies and Theories. In Carrots, Sticks, and Sermons: Policy Instruments and Their Evaluation; Bemelmans-Videc, M.L., Rist, R.C., Vedung, E., Eds.; Transaction Publishers: Piscataway, NJ, USA, 1998; pp. 21-58.

23. Amirtahmasebi, R.; Orloff, M.; Wahba, S.; Altman, A. Regenerating Urban Land: A Practitioner's Guide to Leveraging Private Investment; Urban Development Series; World Bank: Washington, DC, USA, 2016.

24. Rypkema, D.D. Heritage and Development-The Role of Public-Private Partnerships. In Economics and Built Heritage-Towards New European Initiatives; Mälkki, M., Ed.; Helsinki University of Technology: Helsinki, Finland, 2008.

25. Radosavljević, U. Conditions Influencing Waterfront Development and Urban Actors Capacity as a Strategic Response. Spatium Int. Rev. 2008, 17-18, 78-83. [CrossRef]

26. Latham, D. Creative Re-Use: Working with the Building. J. Archit. Conserv. 1999, 5, 7-23. [CrossRef]

27. Oktay Vehbi, B.; Önal Hoşkara, Ş. A Model for Measuring the Sustainability Level of Historic Urban Quarters. Eur. Plan. Stud. 2009, 17, 715-739. [CrossRef]

28. Despotović, J. Očuvanje kulturne baštine-U svetlu naših i evropskih propisa. Leskov. Zb. 2007, XLVII, 19-28.

29. The Government of the Republic of Serbia. The Spatial Plan of the Republic of Serbia (in Serbian); Official Gazette of the Republic of Serbia: Belgrade, Serbia, 2010; no. 88/10.

30. The Government of the Republic of Serbia. Sustainable Urban Development Strategy of the Republic of Serbia until 2030 (in Serbian); Official Gazette of the Republic of Serbia: Belgrade, Serbia, 2019; no. 47/19.

31. The United Nations Conference on Human Settlements. HABITAT III Global Human Settlements Conference. [Internet]. 2016. Available online: http://habitat3.org/the-conference/about-habitat-3/ (accessed on 17 October 2019).

32. Vujošević, M. Collapse of strategic thinking, research and governance in Serbia and possible role of the spatial plan of the Republic of Serbia (2010) in its renewal. Spatium Int. Rev. 2010, 23, 22-29. [CrossRef]

33. Stanilov, K. Urban Planning and the challenges of post-socialist transformation. In The Post-Socialist City-Urban Form and Space Transformations in Central and Eastern Europe after Socialism; Stanilov, K., Ed.; Springer: Dodrecht, The Netherlands, 2007; pp. 413-426.

34. Salet, W.; Faludi, A. The Revival of Strategic Spatial Planning; Royal Netherlands Academy of Arts and Sciences: Amsterdam, The Netherlands, 2000.

35. Križanić, T.P.; Šovljanski, R. Priručnik za Strateško Planiranje i Upravljanje Lokalnim Razvojem u Republici Srbiji; Friedrich Ebert Stiftung: Novi Sad, Serbia, 2010.

36. Statistical Office of the Republic of Serbia: Census 2011. Available online: https://www.stat.gov.rs/en-US/ oblasti/popis/popis-2011 (accessed on 15 November 2019).

37. Premović-Aleksić, D. Islamski Spomenici Novog Pazara; Muzej Ras Novi Pazar: Novi Pazar, Serbia, 2013.

38. Popadić, M. Architect Amir Ćorović and Project of City Center in Novi Pazar. Novopazar. Zb. 2009, 32, 209-225.

39. Nešković, J.; Folić, N.; Đorđević, S.; Radović, R. Stara Čaršija u Novom Pazaru; Zavod za Zaštitu Spomenika Kulture Kraljevo: Kraljevo, Serbia, 1988.

40. Radosavljević, U.; Đorđević, A.; Živković, J.; Lalović, K.; Đukanović, Z. Educational projects for linking place branding and urban planning in Serbia. Eur. Plan. Stud. 2019. [CrossRef]

41. Kadijević, A. O proučavanju i vrednovanju graditeljskog nasleđa novijeg doba u Novom Pazaru. Novopazar. Zb. 1995, 19, 193-203.

42. Mulić, I. Komponente Održivog Razvoja Tradicionalnog Neimarstva Sandžaka-Magistarska Teza; Evropski Centar za mir i Razvoj EPCD: Novi Pazar, Serbia, 2008.

43. The Government of the Republic of Serbia. Ordinance on the Energy Performance of Buildings [in Serbian]; Official Gazette of the Republic of Serbia: Belgrade, Serbia, 2011; No. 61/2011.

44. Calabrò, F.; Della Spina, L. The Public-Private Partnership for the Enhancement of Unused Public Buildings: An Experimental Model of Economic Feasibility Project. Sustainability 2019, 11, 5662. [CrossRef] 
45. Stubbs, M. Heritage-sustainability: Developing a methodology for the sustainable appraisal of the historic environment. Plan. Pract. Res. 2004, 19, 285-305. [CrossRef]

46. The European Commission: Quality of Life Indicators-Measuring Quality of Life. Available online: https://ec.europa.eu/eurostat/statistics-explained/index.php/Quality_of_life_indicators_-_measuring quality_of_life\#Framework_for_measuring_quality_of_life2019 (accessed on 12 September 2019).

47. Radosavljević, U.; Đorđević, A.; Lalović, K.; Živković, J.; Đukanović, Z. Nodes and Networks: The Generative Role of Cultural Heritage for Urban Revival in Kikinda. Sustainability 2019, 11, 2509. [CrossRef]

(C) 2020 by the authors. Licensee MDPI, Basel, Switzerland. This article is an open access article distributed under the terms and conditions of the Creative Commons Attribution (CC BY) license (http://creativecommons.org/licenses/by/4.0/). 